Review

\title{
Sustainable Drainage Practices in Spain, Specially Focused on Pervious Pavements
}

\author{
Daniel Castro-Fresno, Valerio Carlos Andrés-Valeri, Luis Angel Sañudo-Fontaneda and \\ Jorge Rodriguez-Hernandez *
}

Construction Technology Research Group (GITECO), Department of Transports, Projects and Processes Technology, Civil Engineering School, University of Cantabria, Santander 39005, Spain; E-Mails: castrod@unican.es (D.C.-F.); andresv@unican.es (V.C.A.-V.); sanudola@unican.es (L.A.S.-F.)

* Author to whom correspondence should be addressed; E-Mail: rodrighj@unican.es;

Tel.: +34-942-20-39-43; Fax: +34-942-20-17-03.

Received: 5 November 2012; in revised form: 14 December 2012 / Accepted: 6 January 2013 /

Published: 23 January 2013

\begin{abstract}
The Spanish climate is full of contrasts, with torrential rains and long droughts; under these conditions, appropriate water management is essential. In Spain, until the end of the twentieth century, water management and legislative development lagged behind other more developed countries. Nowadays, great efforts are being made to reverse this situation and improve both water management and legislation in order to control the two main problems related to stormwater management in cities: floods and diffuse pollution. In this context, Sustainable Urban Drainage Systems (SUDS) were developed as the main solution to these problems. The study of these techniques started in the 1970s in the USA, but they were not studied in Spain until 1993 when the University of Cantabria and CLABSA started to look into solutions for stormwater management. After 20 years of research and application, sustainable drainage in Spain is still behind other countries in spite of the efforts to change this situation, notably by the University of Cantabria with 10 years of experience in these techniques, mainly regarding pervious pavements, where more than 13 related research projects have been carried out. The future challenges focus on the application of pervious pavements for Urban Hydrological Rehabilitation.
\end{abstract}

Keywords: SUDS; BMP; water management; pervious pavement 


\section{Introduction}

Spain is a country whose climate is full of contrasts, alternating periods of long droughts and torrential rains [1], especially in the Mediterranean regions. This situation had led to the urgent need to manage stormwater properly to avoid lack of water resources in dry areas in the southern part of the country and to manage high volumes of rainfall in northern regions.

Cities have been the central point of social, cultural and economic development since ancient times. From the earliest human settlements, the choice of a suitable location which favors social, political and economic activities was a fundamental goal, which was valued together with climate and soil due to their influence on agricultural activities and the proximity of sources of drinking water and mineral resources [2].

Since the times of the Roman Empire, water has been regarded as a precious and essential resource to ensure the prosperity of a settlement. The Roman Empire managed the urban water cycle from water supply to waste water collection using a two pipe system [3]. This civilization gave a privileged place to water management in the development of cities as can be seen in the notable number of hydraulic structures and buildings designed for the conveyance of drinking water to urban areas and also those intended for sewage [4]. Later, during the eight centuries of Islamic occupation of the Iberian Peninsula, Muslims treated water with great relevance. Applications related to recreational use should be highlighted since many hydraulic works related to water management were undertaken. The numerous cisterns for rainwater collection built across Spain are especially noteworthy, both for domestic use and constructions of great importance for supplying entire populations [4]. These engineering works were especially important in cities and fortifications away from watercourses in which it was necessary to take advantage of available water resources or as alternative water source for potential city sites.

At the beginning of the Middle Ages, the importance given to water as a source of health and wellbeing diminished and there was an unprecedented reversal. During this time, wastewater was directly discharged, often into the streets of cities, without any kind of treatment, causing major disease outbreaks [3]. The progressive development and growth of human settlements, particularly during the process of industrialization in the 19th century as a result of the Industrial Revolution and the gradual urban land sealing led to serious health problems in the Spanish population in the late 19th century [5].

From an environmental point of view, the great ancient cities were overcrowded mainly due to the limits of the defensive walls. This situation, together with inadequate or nonexistent infrastructure, meant that the health status of the Spanish population at the beginning of the 20th century was precarious [2]. This society showed huge health, economic and social deficiencies. The high mortality rates were linked to unhealthy situations affecting all areas of people's lives. The shortcomings associated with the use of water were one of the elements most clearly related to health problems. One study conducted by the Health Academy of Catalonia concluded that deficiencies related to the water cycle were among the main determining factors of health among the Catalans. The International Society of Water, founded in the wake of the International Congress on Hygiene in Paris in 1878, highlighted the situation of water and its relation to disease epidemics [5]. Health problems in the main Spanish cities and the importance of proper sanitation systems were demonstrated in the Madrid Congress on Hygiene held in 1898. An important milestone came in 1912 when the "Royal 
Commission on Sewage Disposal" established the standards and tests that should be applied to characterize the effluent treatment facilities in the UK. From that year, the main European cities began to build wastewater treatment plants [3].

Unsuitable water management from urban areas produced stagnation and favored the development of disease-carrying organisms. In addition, the incorrect laying of water pipes favored the contamination of water, resulting in unsafe water, which ultimately was the cause of several epidemics in the late 19th century. This led to the need to quickly evacuate the water from cities, leading to the great revolution in sanitation and wastewater treatment that occurred during the 20th century [3].

With the increasing trend of migration from rural to urban areas during the 20th century, there was a rapid growth of cities, thereby increasing impervious areas and altering natural drainage systems. This situation has worsened in recent decades due to the alteration of the natural water-related processes that uncontrolled urbanization causes. This has led to the policy of combined sewage systems that evacuate rainwater as quickly as possible from urban zones [6].

Given the rapid development and growth of urban areas, the problems caused by stormwater have become important because sewer systems are unable to completely remove urban runoff produced during highly intense rainfall. There are two main problems:

- Inefficient management of the runoff may lead to local flooding in urban areas with an overloaded sewage system. In this context, the largest urban areas are at high risk due to their high population density, which makes them especially vulnerable [7];

- Water quality aspects described in several studies confirm the contamination present in surface runoff, highlighting the distributed origin of the pollutants that cause diffuse pollution [8]. This pollution comes from substances deposited on the urban surfaces and subsequently washed away by runoff, so is directly related to the land uses [9].

There are two possible solutions to these problems: increasing the collectors' capacities in urban areas with drainage problems or augmenting the infiltration capacity of urban surfaces [6]. Although both options have an additional cost, it is clear that the capacity of collectors should increase at the same pace as the city grows in area and population. Therefore, collectors must be periodically extended to meet new needs, which results in higher treatment and pumping costs. Thus, the option of increasing the infiltration capacity of urban surface may be attractive in terms of sustainability.

In this context sustainable drainage techniques have emerged as a set of systems that reproduce the natural processes of water management. Their purpose was to mitigate the peak flow volumes of runoff and reduce water pollution by implementing mechanisms of infiltration, transport and retention. The initial development occurred in USA in the 1970s with the name of Best Management Practices (BMPs) and then, in the late 1980s in Europe, with the name of Sustainable Urban Drainage Systems (SUDS). Back in the early 1990s, the concept was introduced in Australia with the name Water Sensitive Urban Design (WSUD).

In Spain, these techniques have had different names since their introduction in the early 1990s. Originally called Compensatory Infiltration-Retention Techniques (Técnicas Compensatorias de Infiltración-Retención-TECIR), different names were later coined to define them, such as Sustainable Urban Drainage Techniques (Técnicas de Drenaje Urbano Sostenible_-TEDUS) or Sustainable Urban Drainage Systems (Sistemas Urbanos de Drenaje Sostenible-SUDS). 


\section{Legislative Development in Spain}

The conceptual foundations of the current legal regulation of water in Spain date back to the beginning of the 19th century, when in the Cádiz Courts the liberal ideal emerged whereby "idle resources of the nation should be mobilized and put to the service of creating wealth for the country." This idea was collected and explicitly formalized in the Spanish Water Acts of 1866 [10] and 1879 [11]. In 1924, the Regulation of Works, Services and Municipal Assets [12] was passed, transferring the powers relating to water supply and sanitation to municipalities that were required to manage these works of general interest. The process of creation of the "Hydrographic Confederations," the most important institutions within the public administration in water management was started two years later in 1926. Their purpose was to study, build and operate water infrastructures of general interest and to manage public water in the river watershed under their control.

While Spain had not yet legislated any directive or law on water quality and pollution control, the United States signed the Federal Water Pollution Control Act in 1948 [13], with the objective of limiting the pollution discharges by industries and ensuring clean water in rivers and lakes to allow fishing activities. This act underwent various amendments over the decades and, in 1977, the name was changed to the Clean Water Act [14], which highlighted the problem of diffuse pollution and set out the immediate objective of finding solutions to it, an activity which intensified after the Water Quality Act of 1987 [15].

Meanwhile, the complexity of the water sector, new technologies and socio-political changes in Spain made it necessary to enact a new Spanish Water Act in 1985 [16] that regulates the incorporation of the autonomous regions derived from the 1978 Spanish Constitution and the acceptance of the principles of integrated management, efficiency, respect and unity of the water cycle. In 1986, Spain entered the EU, and its entrance represented a turning point in legislation regarding water, primarily due to joining a supranational entity with the obligation of complying with the policies set out by this organism. Thus, since the approval of the EU Directive 75/440/EEC [17] on the water quality required in surface water intended for drinking, a series of directives that regulate water quality and reduce pollution have been passed. The most important were: EU Directive 91/271/EEC [18] on the treatment of urban wastewater, which established the need to treat urban wastewater in big municipalities; EU Directive 2000/60/EC or the Water Framework Directive (WFD) [19] is one of the most ambitious in terms of EU environmental legislation because it establishes a common policy on water management, introducing the concept of sustainable development; and EU Directive 2007/60/EC [20] on the assessment and management of flood risks.

In 2001, through the Spanish Royal Decree 1/2001 [21], a revised text was published of the Water Act regulating the use of water and establishing basic standards for the protection of inland, coastal and transitional waters. In addition, the act established state competence in water planning. The regulation in this text was subsequently developed through the Spanish Royal Decree 606/2003 [22]. The Spanish National Hydrological Plan was approved in the Spanish Law 10/2001 [23], which brought about a large development in national water policy. Among the most important measures in this plan is the intention to transfer water between river watersheds to meet the needs of those areas most affected by drought. Given the public controversy raised by these measures, this text was amended, resulting in the current National Water Plan. It promotes the use of new technologies, such as desalination and water 
reuse to mitigate deficiencies in the most problematic areas, instead of such controversial transfers which remain only as a measure that could be applied when faced with the impossibility of finding other alternatives. Due to the preoccupying droughts in extensive areas of the country, techniques for saving and reuse of treated water, have become especially important. In response to this situation, the Spanish Royal Decree 1620/2007 [24] was approved, which developed the legal status of the reuse of treated water. This standard established the legal mechanisms that enable the direct use of treated water as an alternative water resource, including provisions relating to permitted uses and minimum quality criteria required depending on the use of the reclaimed water. It also set out measures to promote the development of plans to use and reuse water resources more efficiently, and introduced the concept of "regenerated water" as that which is treated and reused before being returned to the environment.

The recent Spanish Royal Decree 1290/2012 of 7 September [25] is especially interesting because it indicates the need for detailed technical studies of river basins at the municipal level, including land use and types of surfaces, with the obligation of encouraging the use of best practices and highlighting the need to propose measures to limit the contribution of rainwater to collectors.

As mentioned above, Spain is divided into Hydrographic Confederations that control their own watersheds. However, although the Spanish state establishes minimum requirements, different entities of regional governments are largely responsible for water management and may pass more restrictive local laws than the national ones. In this context of legislative foundations, the first reference to SUDS urban application occurred in 1997, when CLABSA (Clavegueram de Barcelona S.A) included recommendations for the Implementation of TEDUS in an urban paper "Special-PECLAB'97 Sewage Plan Barcelona" [26]. After that, different Spanish regions adopted specific regulation including various SUDS references.

The Madrid City Council published the new "Ordinances for the efficient use of water" [27] and a manual of "Best Practices in Architecture and Urbanism" [28] in 2009, including filtering criteria and retention in origin for stormwater, called "New non-conventional separate sewer systems."

In 2009 the ITOHG (Instructions for hydraulic works in Galicia) [29] was published by the Government of Galicia with specific requirements on sustainable management of stormwater.

Later, in 2010, at the request of the Barcelona City Council, CLABSA prepared a technical paper on recommendations for TEDUS, indicating types and location in the city of Barcelona and a number of recommendations regarding the maintenance plan required to ensure efficient operation over time.

\section{SUDS Research in Spain}

The signing of the Clean Water Act and the constitution of the U.S. EPA in 1972 highlighted the importance of diffuse pollution from runoff as it runs through agricultural, industrial and urban land [30]. In the search for solutions that would help to reduce the problems of runoff volumes and diffuse pollution, in the U.S they began to study BMPs. The first scientific publication was written by Thelen et al. [31], who studied the application of pervious pavements to control runoff and different materials to be used as porous surfaces, seeking to optimize the infiltration capacity. Since the beginning of this research line on BMPs, numerous research projects and scientific publications have been produced. 
This research line reached Europe in the early 1980s, and a major research effort on implementation of BMPs was made in the UK. The first scientific publication was by Pratt [32], who studied a group of techniques that was originally called infiltration techniques. The first scientific paper about permeable pavements developed in Europe was written by Pratt et al. [33]. The term SUDS, as these techniques were called in the UK, appeared for the first time in 2001 in a scientific paper by D'Arcy and Frost [34].

In 1993, the concept of sustainable drainage arrived in Spain. Related to this, the work undertaken by the Environmental Engineering Group (Grupo de Ingeniería Ambiental-GIA) of the University of Cantabria, led by Iñaki Tejero, should be highlighted. This research group studied alternative stormwater drainage techniques, leading to the first Spanish master's dissertation on this subject. Some of the early works carried out by this team are very relevant, such as: Cervigni, Temprano González and Cano [35-37].

At the same time, CLABSA studied the application of TECIR for the drainage of stormwater in Barcelona. These studies culminated in 1995 with the publication of the first scientific paper on sustainable drainage in Spain with a specific section dedicated to TECIR [38], which recognized the problems that urban development and the resulting land waterproofing generated in the natural water cycle and combined sewage systems. It also introduced the concepts of "first-flush" and diffuse pollution. Several solutions were described to deal with the problem, including TECIR, underscoring its relevance in reducing stormwater runoff and pollution and highlighting the role of porous pavements. This first paper is of particular importance in disseminating the concept of sustainable drainage in Spain. Temprano González et al. [39] subsequently delved into the concept of TECIR, classifying the possible actions to reduce runoff problems in structural and non-structural measures and mentioning for the first time in Spain the concept of source control of urban runoff. The role given to permeable pavements is remarkable in reducing pollution and as a solution to reduce runoff, increasing infiltration into urban land, and providing the outline of a typical section of a permeable pavement.

González del Tánago [40] also discussed the problems associated with diffuse pollution in agricultural areas, such as nutrients and pesticides ending up pouring into natural channels. They propose bio-assimilation methods for filtering polluted water from agricultural areas before discharging it into rivers, through green filters and riparian vegetation strips or "buffer-strips".

The first bibliography published in Spanish that deals with the concept of diffuse pollution and MPCs (Mejores Prácticas de Control), as a translation of the Stormwater BMPs (Best Management Practices) of the United States was undertaken by Jimenez Gallardo [41].

The EU research project called DAYWATER started in 2002 with the main aim to improve Urban Stormwater Management. This project demonstrates the European effort in Stormwater management and SUDS implementation. The focus of this project is on the quantity and quality of storm water in urban areas. The aims of this project were to develop an Adaptive Decision Support System (ADSS) to enable the identification of the most suitable and cost effective solutions for a range of urban situations, and to support storm water managers by implementing measures with the best effects. DAYWATER also aimed to characterize the decision-making process, promoting the use of stormwater source control and integrated water management in urban policy making and catchment area management, disseminating technical information on BMPs and providing models for the analysis of pollution loads and environmental risk assessment [42]. 
It was not until 2003 when the SUDS concept started to be used in Spain. The investigators in Coventry University began to collaborate with the Ecology, Roads and Construction Engineering Groups of the University of Cantabria in a research line on design and construction of pervious pavements in Spain.

The first Spanish research project in SUDS started in 2003 in the Construction Group of the University of Cantabria, entitled "Development of New Pervious Pavements for Biodegrading Hydrocarbons (FIDICA)," funded by the Spanish Government. The main objective of the project was the design of pervious pavements made with as much recycled material as possible, while being able to catch and treat surface runoff water, especially in car park areas. Thus, the discharge would not cause contamination problems in the receiving environment. This project was divided into two different parts: firstly, the study of water quality, focusing on microbiological aspects of hydrocarbon degradation; and, secondly, the mechanics of permeable pavements such as hydraulic flow, storage and filtering in the various components of pervious pavements $[43,44]$. The final goal of the project was to study the feasibility of using permeable pavements in Spain and to determine the optimum construction materials in terms of cost-effectiveness. The team also studied the feasibility of using geotextiles based on Polyester and polyethylene for this purpose. In the FIDICA project, different types of permeable surfaces, filling materials and geotextiles were studied, both at real and laboratory scale [44]. To develop the project, apart from laboratory tests and intermediate scale tests, 15 car park bays were constructed with different types of permeable surfaces in the car park of "La Guia" in Gijón [43]. The project was presented at the 10th ICUD $[43,44]$, explaining the experimental methodology, the main objectives of the project and preliminary results.

Before starting this research line, a major literature review was conducted of the existing sustainable drainage techniques, which resulted in a scientific paper [45] that introduced the term "SUDS" (Sistemas Urbanos de Drenaje Sostenible), adapting the same acronym used in the UK into Spanish (Sustainable Urban Drainage Systems), and offering a classification based on the different characteristics of Spain. It was also necessary to develop laboratory instruments to perform various tests on permeable pavements, leading to the development of the Cantabrian Fixed (CF) Infiltrometer [43] and the Cantabrian Portable (CP) Infiltrometer [46].

The CF Infiltrometer is a device used to evaluate the infiltration capacity of permeable pavements in a laboratory. It is based on previous designs developed in Coventry University [47]. The device (Figure 1) consists of a holder, with adjustable height and tilt, on which you place a $50 \times 50 \mathrm{~cm}$ specimen surface. Direct precipitation is simulated through drippers connected to a water source and runoff is simulated with a perforated pipe at one end of the specimen. The device has five containers located below the cylinder, which enable the collection of the infiltrated water at intervals of $10 \mathrm{~cm}$, and another to collect the residual runoff $[43,48]$.

Thanks to this device, in 2004, another University of Cantabria research project, for the development of a paving stone designed for use in pervious pavements, led to an industrial design [49] that is currently utilized by Pavers Montserrat. Furthermore, Castro et al. [48], using the CF Infiltrometer, studied the influence of the inclination of the pavement and the clogging conditions on the infiltration capacity of permeable pavements made of impervious concrete blocks. They studied four different types of impervious concrete blocks with different geometric arrangements of permeable joints as can be seen in Figure 2. 
Figure 1. Detail of Cantabrian Fixed Infiltrometer [50].

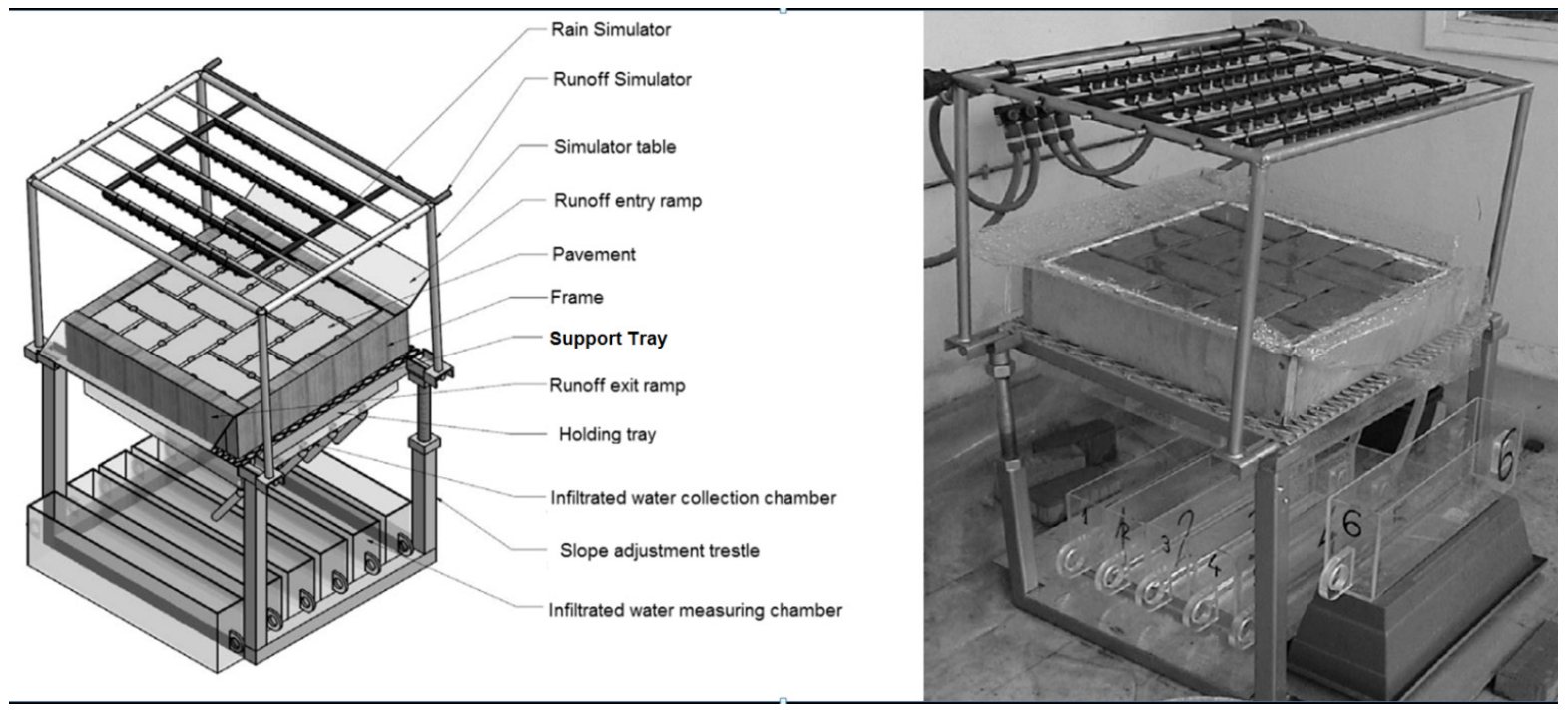

Figure 2. Permeability results of different ICBP surfaces obtained with CFI, (self-made from the results obtained by Castro et al. [48]).

\begin{tabular}{|l|c|c|c|c|}
\hline Concrete block & B1 & B2 & B3 & B4 \\
\hline Slot shape & Rhomboidal & Circular & Square & 603.2 \\
\hline $\begin{array}{l}\text { Infiltration area } \\
\left(\mathrm{mm}^{2}\right)\end{array}$ & 600.0 & 600.0 & 603.2 & \\
\hline & &
\end{tabular}

B1

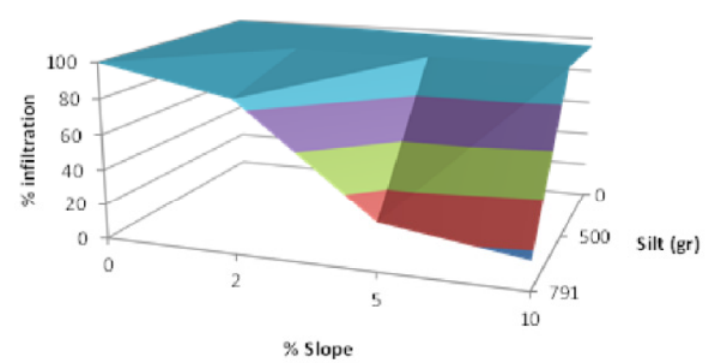

$=0-20=20-40=40-60 \quad=60-80=80-100$

B3

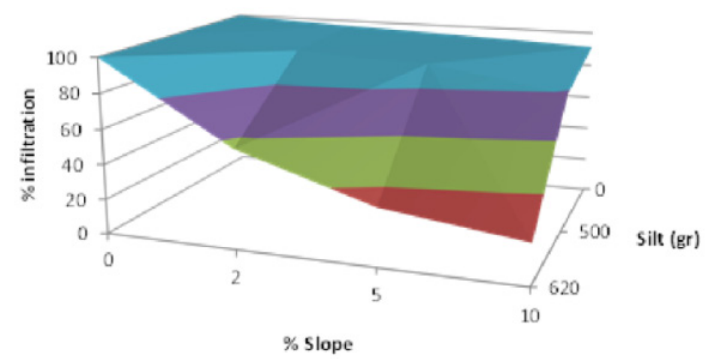

$=0-20=20-40=40-60=60-80=80-100$
B2

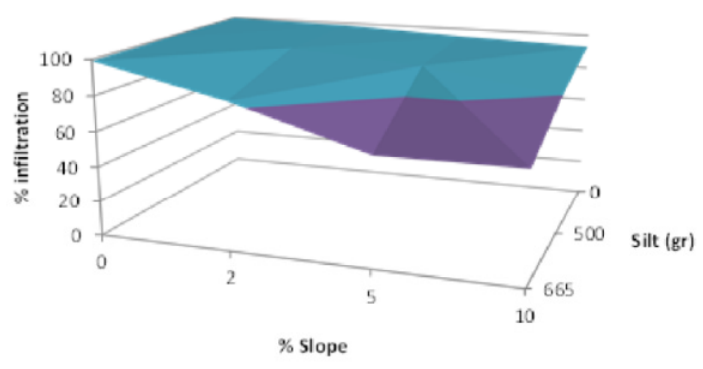

$=0-20=20-40=40-60=60-80=80-100$

B4

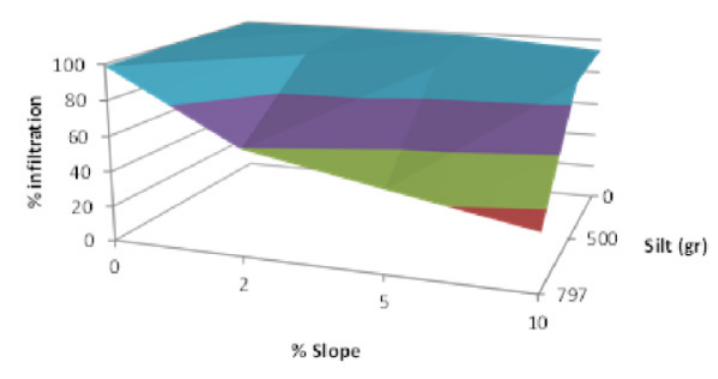

$=0-20=20-40=40-60=60-80=80-100$ 
They concluded that the blocks with longer, narrower slots performed better than the blocks with shorter, wider gaps. They also concluded that the amount and particle size of the silt affect the hydraulic performance, and that the reduction in infiltration capacity increases dramatically when the pavement surface is fully clogged, and when this is combined with an increasing gradient.

In order to evaluate the effect of runoff in fully clogged surfaces, González-Angullo et al. [51] used the CF Infiltrometer applying different rainfall intensities and using different slopes of the pavement in 2008 obtaining the results showed in Figure 3.

Figure 3. Evolution of permeability in ICBP surface obtained with CFI: (a) Runoff resistance results; (b) Linear regression model [51].

(a)

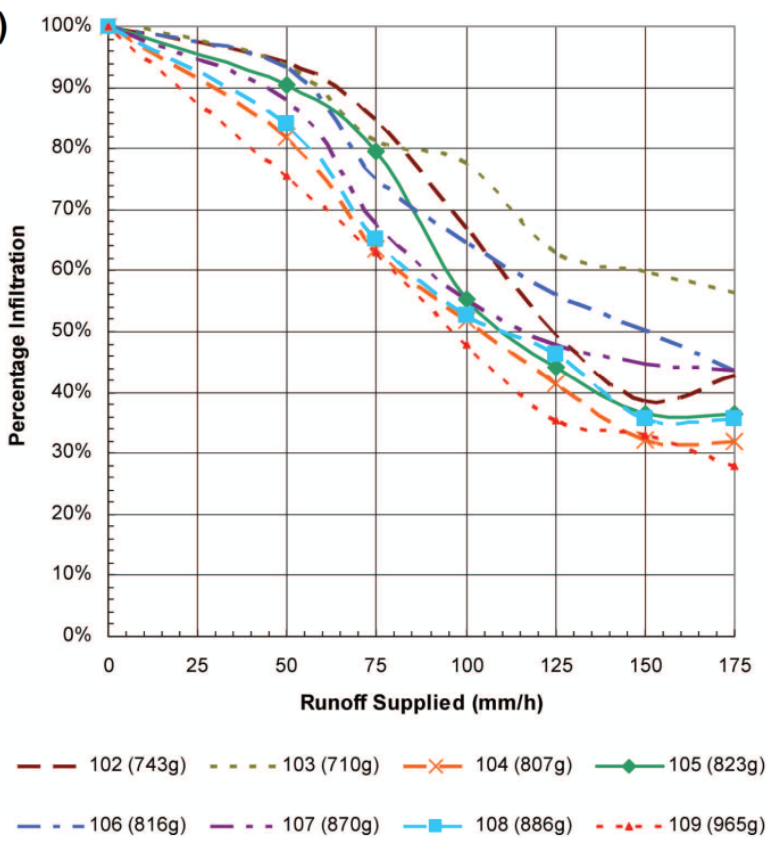

(b)

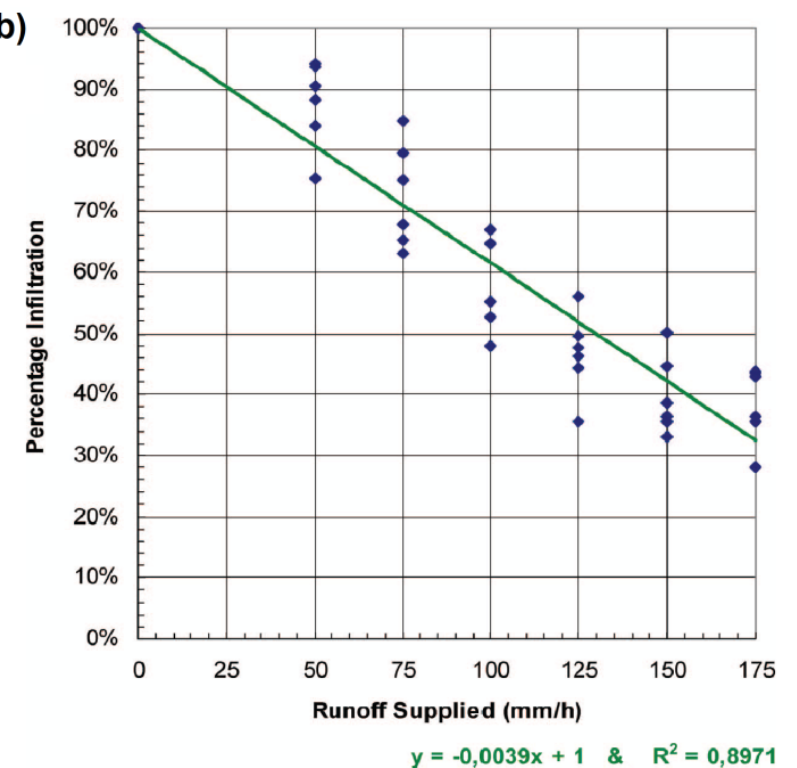

Later, in order to complete this information, Rodriguez-Hernandez et al. [52], using the same test apparatus, evaluated the infiltration capacity of a porous asphalt mixture under different clogged conditions and slopes (Figure 4) concluding that a suitable design of a porous bituminous mixture, with a void percentage that increases with depth, along with surface brushing are enough to ensure and maintain a good infiltration capacity. They provided three regression models corresponding to three clogging scenarios that explain the behavior.

In the 12th ICUD, Sañudo-Fontaneda et al. [53] introduced a new CF Infiltrometer, improved by the addition of the measurement of subsurface runoff and improving the accuracy by using flow meters that help to monitor the rainfall intensity. With this improved apparatus, Sañudo-Fontaneda et al. [54] studied the infiltration behavior of Interlocking Concrete Block Pavements (ICBPs) during their operational life in a car park, also presenting a statistical analysis based on three regression models corresponding to three clogging scenarios depending on runoff surface length (RSL) and surface slope (SS). All models showed that RSL is a more influential variable than the SS for all clogging scenarios.

Due to the need to assess the infiltration capacity of pavements, the Portable Cantabrian Infiltrometer [46] (Figure 5) was developed to measure the in situ infiltration capacity by simulating different rainfall intensities. 
Figure 4. Permeability results of PA surface obtained with CFI [52].

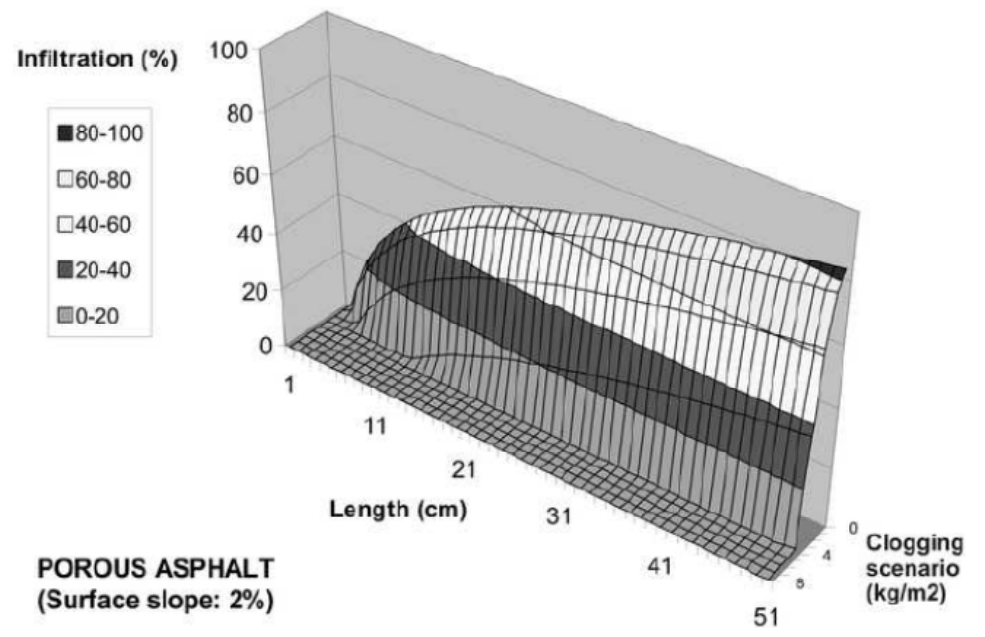

Figure 5. (a) Detail of Cantabrian Portable Infiltrometer; (b) LCS permeameter [50].

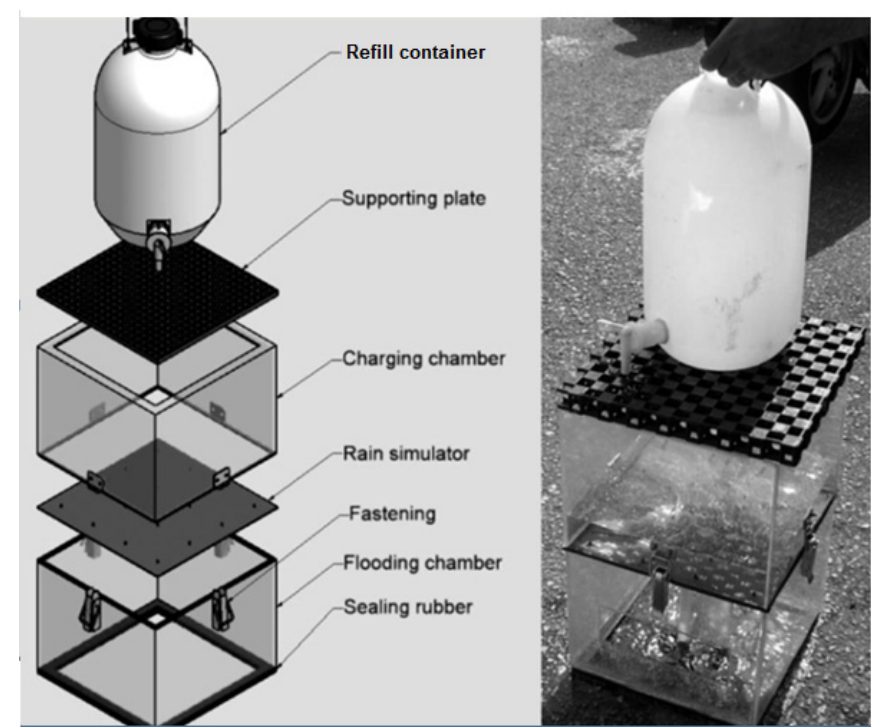

(a)

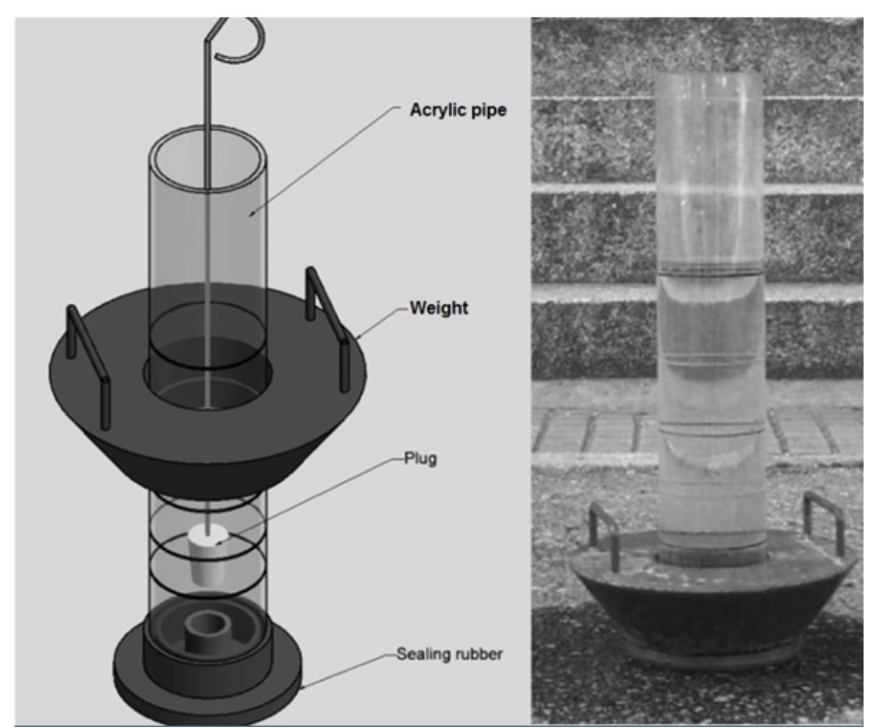

(b)

The device consists of two cubic acrylic containers stacked and separated by a perforated plate fitted with drippers. The upper container is called the charging chamber because, depending on the water load that is placed in this chamber, it will simulate a certain intensity of precipitation through the drippers. The lower chamber is located in direct contact with the ground, sealing the perimeter with Vaseline to prevent leakage of water, and it is called the flooding chamber. In this chamber the water fall simulates rainfall. If the water precipitated is over the infiltration capacity of the studied pavement, the water is retained in the flooding chamber. Measuring the level of the water after a default time helps to determine the infiltration capacity of the pavement [46]. By employing this device Fernández-Barrera et al. [46] tested different pavements of different ages, and the results were compared with those determined by the LCS permeameter [55], similar to the ring permeameter described in the European standard EN 12697-40 European Standard 2005 (Figure 5). The two devices are based on different measurement principles: on the one hand, the LCS permeameter evaluates the infiltration rate by measuring the time taken by a default water volume to infiltrate through the pavement; on the other hand, 
CP Infiltrometer evaluates the infiltration rate measuring the water volume not infiltrated in a default time and comparing with the total water volume used. The results obtained have been treated in order to show the infiltration rates obtained by two devices. The results are shown in Figure 6.

Figure 6. Permeability results obtained with CPI and LCS for different surfaces (self-made, obtained from results obtained by Fernandez-Barrera et al. [46]. (a) LCS obtained results and (b) CPI obtained results.

(a)

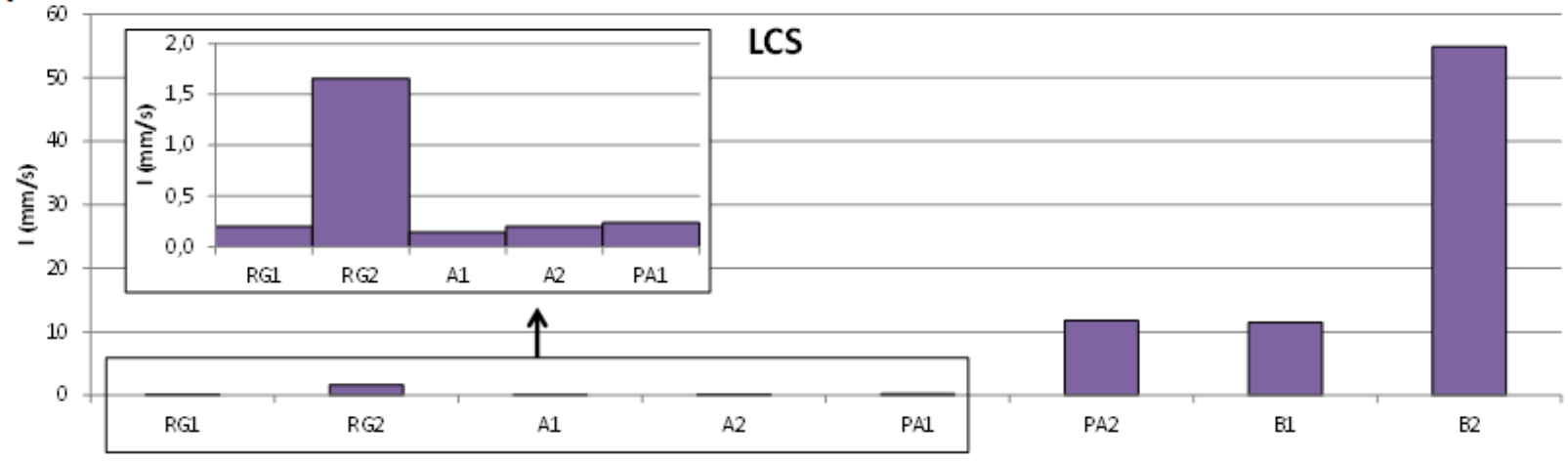

(b)
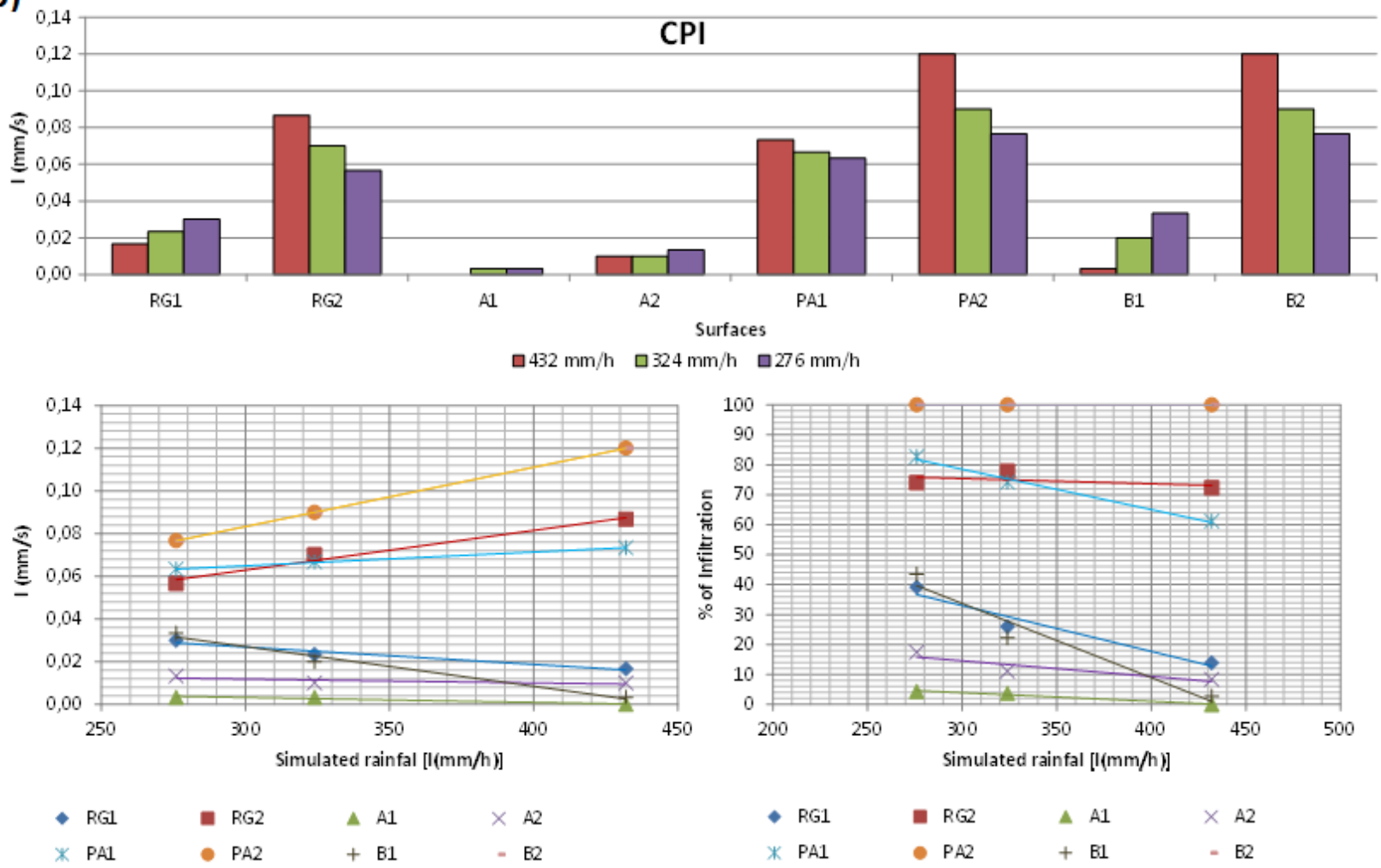

RG1: Grass in clayey soil reinforced with cancrete cells RG2: Grass in sandy soil reinforced with plastic cells A1: New impervious asphalt surface course

PA1: porous asphalt course with high traffic PA2: porous asphalt course with low traffic B1: Concrete blocks with mortar in joints B2: Concrete blocks without filler in the joints

The main conclusions drawn from studies with the CPI and the comparison of results between the two devices were that the CPI can test more surfaces than LCS because it tests specific areas, not only a point, so it can also be used in discontinuous surfaces. Moreover, observing the results, it could be seen that, for impervious surfaces (A1), or surfaces with low permeability, CP was better than LCS 
because it allows more accuracy in low ranges. Although the CP test is generally slower than LCS, the $\mathrm{CP}$ test could be faster than the LCS one for impervious surfaces (A1).

In 2006, the research line continued with a new research project developed by the Construction Group of the University of Cantabria: "Development of new catchment, pre-treatment and on-site treatment systems for water polluted with hydrocarbons proceeding from the surface runoff in impervious pavement parking areas (TRAPI)." This project diversified the research line, through the design of a compact system that can be installed in impervious car parks, providing treatment for polluted runoff due to Total Suspended Solids (TSS) and Total Petroleum Hydrocarbons (TPH).

To carry out this project, a literature review of the major pollutants expected in runoff was carried out by Rodriguez-Hernandez et al. [56]. The authors analyzed several previous studies worldwide on major pollutants in runoff under different land uses, statistically evaluating the significance of the results obtained in these studies. In 2010, Rodriguez-Hernandez et al. [57] published the results of a full-scale prototype, the SCPT (System of Collection, pre-treatment and treatment).

The prototype (Figure 7) consists of an acrylic structure that was divided into three chambers. Water enters into the system through the first, passes through the second chamber or decantation chamber, where the solid particles are decanted and then flows through a filter to enter the third chamber from which the system drains. The efficiency of the system in treating pollutants was studied for TPH and TSS, reaching pollutant reduction rates close to $90 \%$ for both parameters (Figure 8).

Figure 7. Detail of SCPT [57]: (a) Modeled SCPT scheme; (b) Constructed SCPT; (c) Modeled test system used for SCPT; (d) Constructed system for SCPT test.

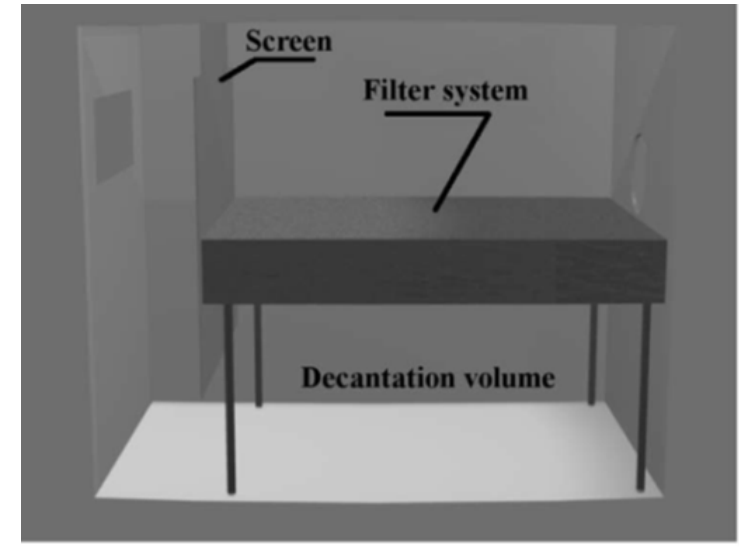

(a)

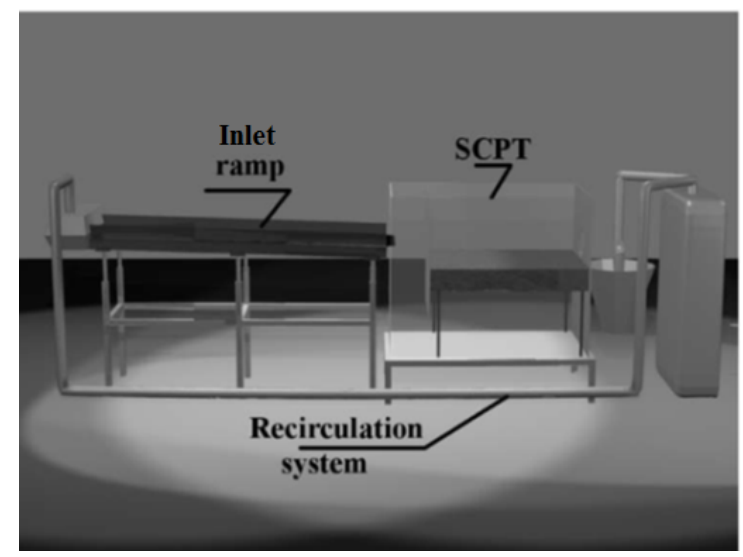

(c)

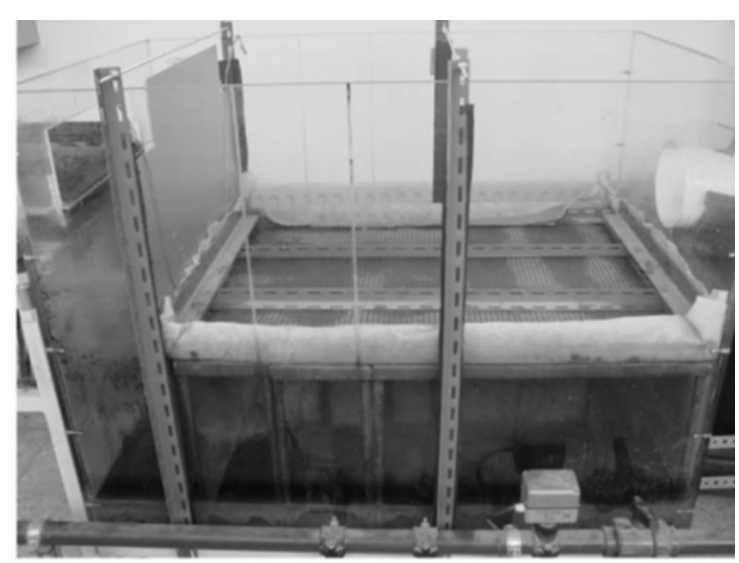

(b)

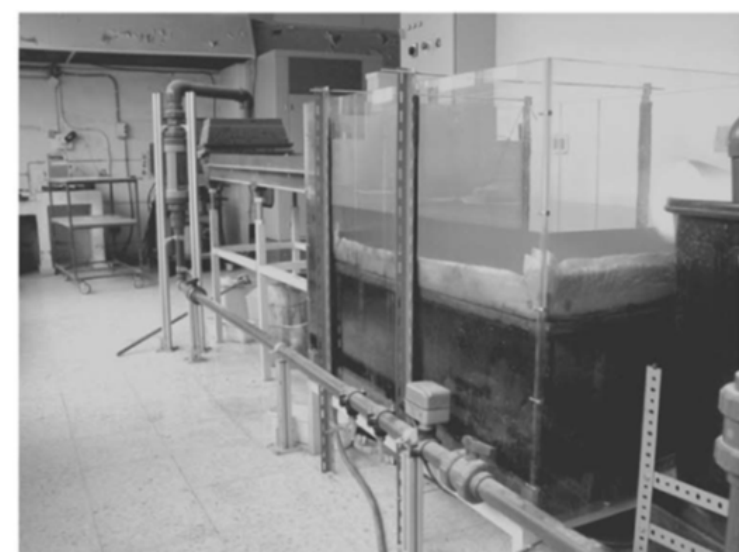

(d) 
Figure 8. Pollutants reduction obtained with SCPT [57]. (a) Solids reduction: EfSH-High

Load Conditions and EfSM-Medium Load Conditions; (b) Oil reduction.

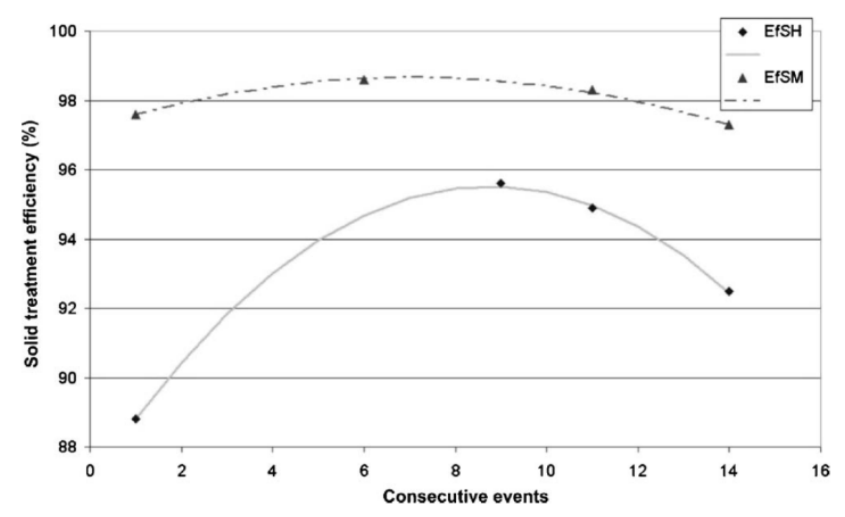

(a)

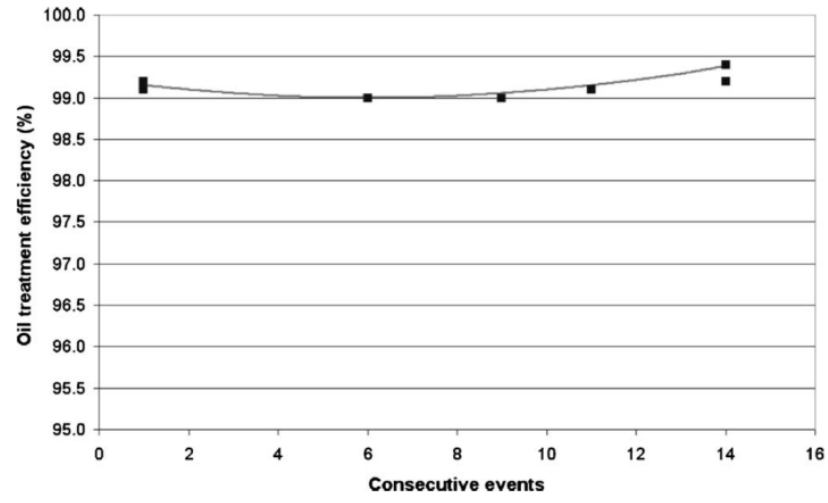

(b)

In order to provide a mathematical model that describes the SCPT pollutant removal, in 2010 Fernández-Barrera et al. [58] attempted to mathematically model the reduction of contamination obtained using the SCPT in terms of the contamination and flow rate supplied to the system. They concluded that the factors which influence the efficiency of treatment of solids are the inflow and the number of geotextile layers in the filter, both factors having a similar importance (Figure 9).

Figure 9. Efficiency in (a) TSS removal; (b) OW removal of SCPT [58].

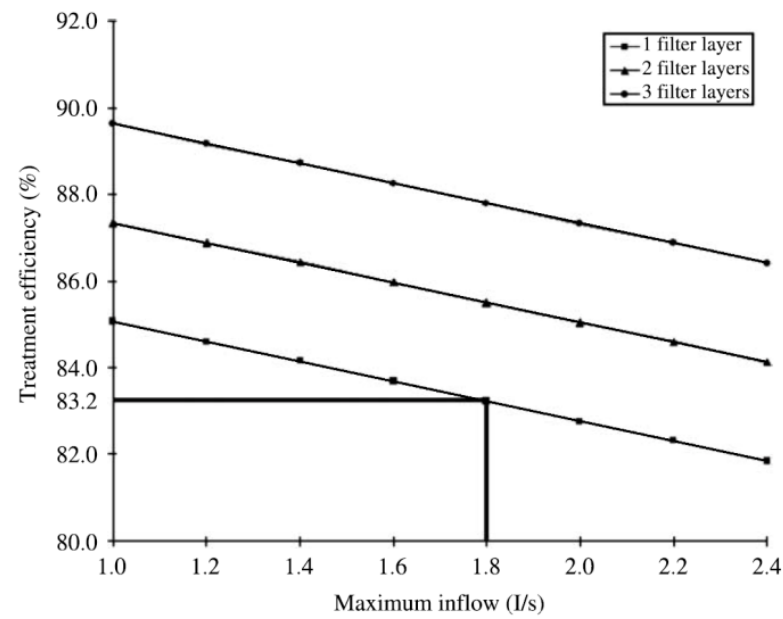

(a)

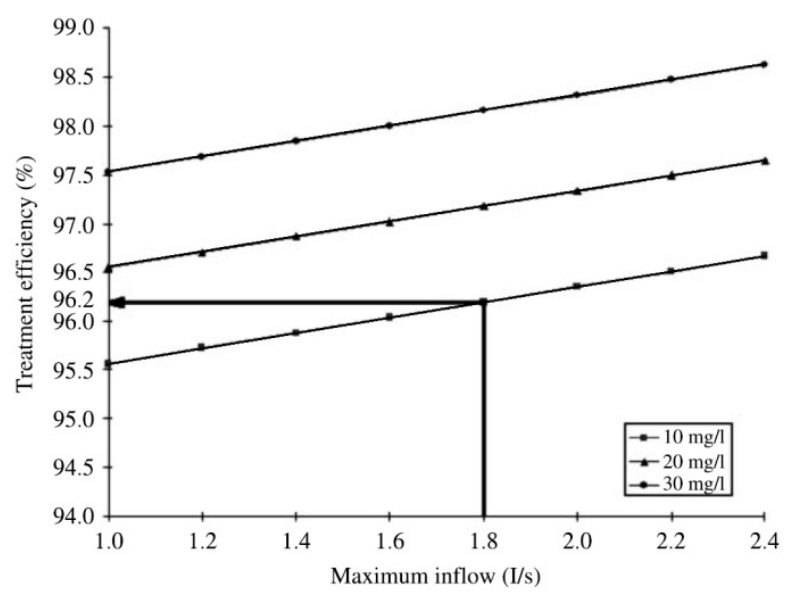

(b)

Later Fernández-Barrera et al. [59] evaluated the performance of the SCPT with different geotextiles that were effective as a support for biofilm, responsible for degrading hydrocarbons.

In Figure 10 can be observed the obtained results, based on which the authors concluded that the hydraulic conductivity of the geotextile material does not undergo significant variations in its behavior due to the different solid and oil loads used during the test with the SCPT. The results also show a clear indication of the negative effect on the hydraulic conductivity of pollutant re-suspension and retention of air bubbles. Finally, the project led to a patent exploited by Impulso and Coprosa, Inc. (Asturias, Spain). 
Figure 10. Hydraulic conductivity for (a) high load; (b) medium load of SCPT [59].

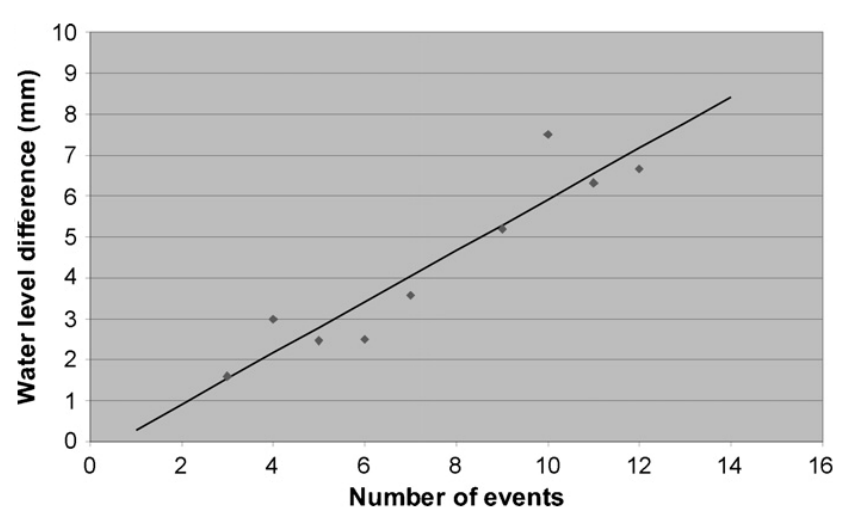

(a)

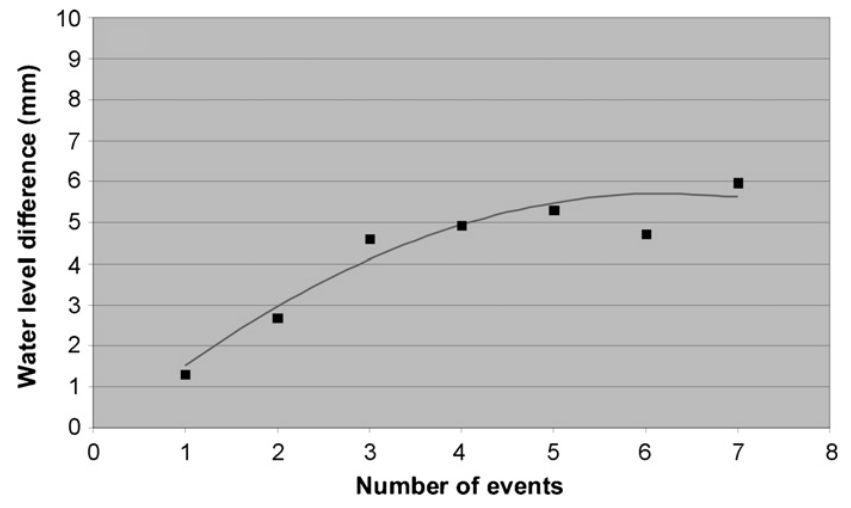

(b)

In 2006, the Construction Group of the University of Cantabria started another research project "Design, research and instrumentation of a parking lot built with hydrocarbon-degrading pervious pavements." In this project, an experimental open air car park with 45 parking spaces was built in "La Vaguada de las Llamas" park in Santander (Figures 11 and 12). The aims of this project were:

- Study the performance of different types of pervious pavements under real conditions. Different surfaces were used: grass reinforced with concrete cells, grass reinforced with plastic cells, porous asphalt, porous concrete, and impervious concrete blocks with permeable joints;

- Study the influence and performance of various geotextiles and surfaces in relation to the quantity and quality of water. This project focused on the ability of geotextiles to support the biofilm that degrades hydrocarbons and to prevent evaporation of stored water.

The project was presented at Novatech 2010 by [60], explaining the research methodology and preliminary results obtained from the collected data.

Figure 11. Las Llamas experimental car park [61].

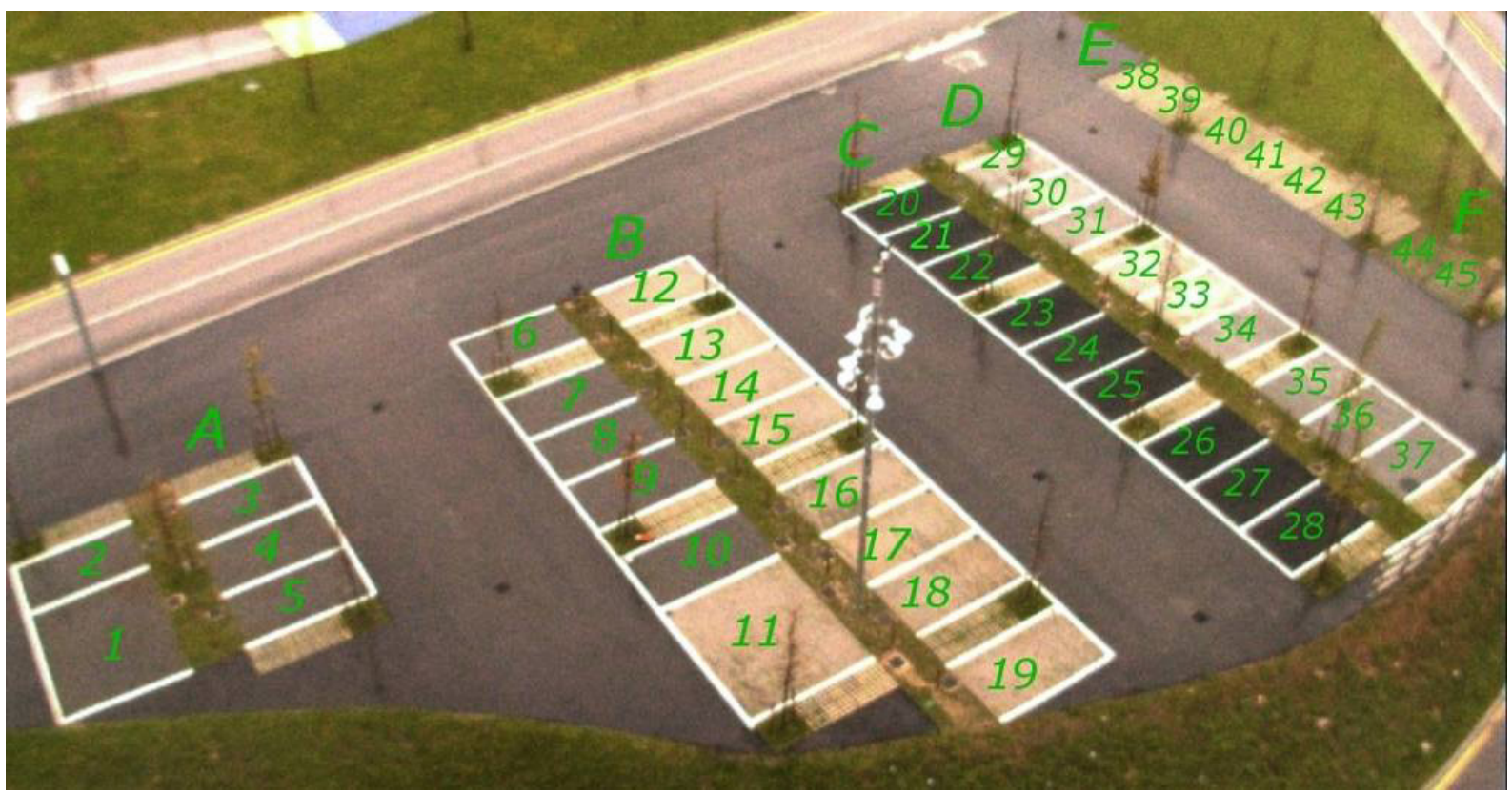


Figure 12. Cross section of Las Llamas experimental parking bay [61].

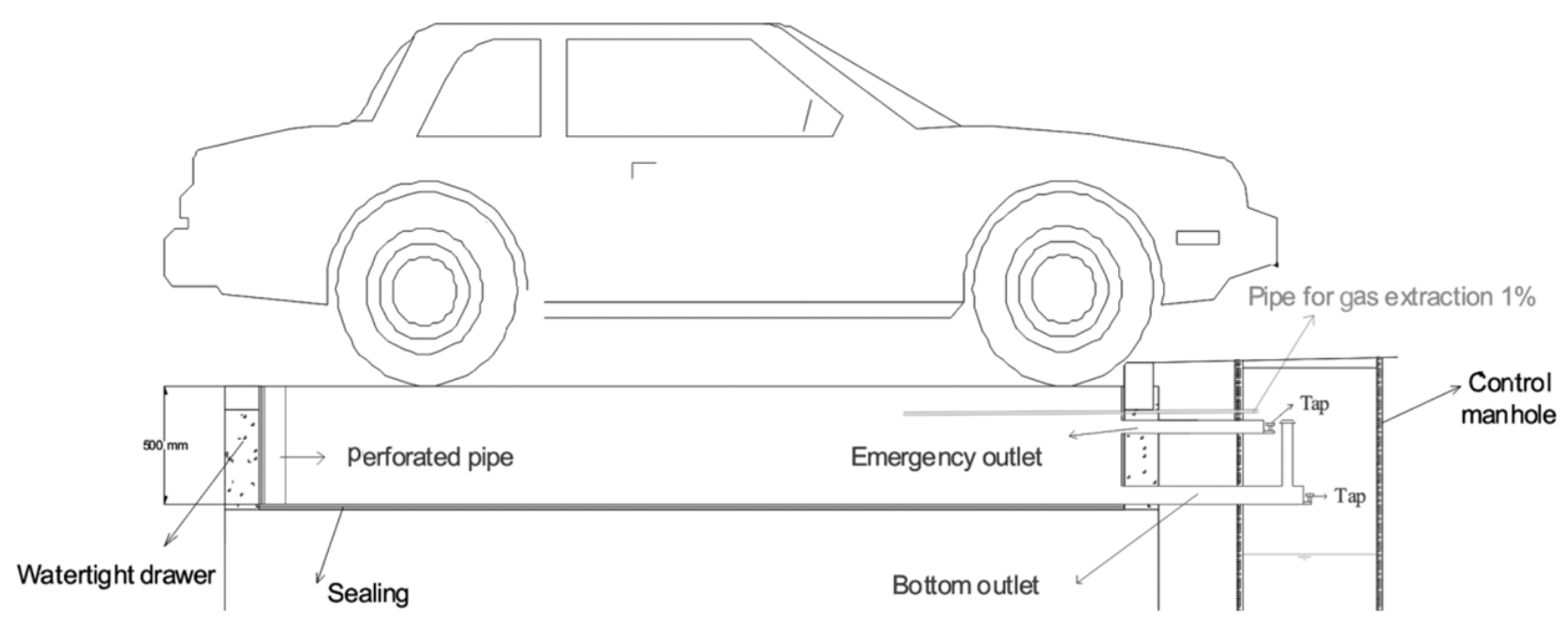

In 2011, Gomez-Ullate et al. [62] analyzed the experimental car park's function in the treatment of runoff quantity concluding that the surfaces could be grouped in three different groups with similar properties: open, closed, and green ones. They also concluded that the influence of the surface is greater than the geotextile's on the infiltration capacity and that this type of system can be very useful in the temporary storage of water, having demonstrated its high capacity to retain water.

Later Gomez-Ullate et al. [63] analyzed the results of different stored water quality parameters in the parking lots demonstrating that after one year of storage, under Spanish law, water quality is good enough to be used for irrigation of green areas or road cleaning.

In 2007, and continuing this line, the researchers started the project "Design, control and monitoring of a linear system of sustainable drainage," which aims to complete the line by adding the study of a linear SUDS application in roads and car park. In particular, it studies the effectiveness in reducing pollutant in sustainable drainage systems: a swale and a filter drain, comparing the outflow water with a conventional concrete ditch. To achieve this aim, three experimental trenches were constructed in a roadside car park in the Hotel "El Castillo del Bosque de La Zoreda" near the city of Oviedo. In 2012, Andrés-Valeri et al. [64] concluded that outflow water quality from sustainable systems is significantly better than a conventional concrete ditch, highlighting the filter drain that provides the best pollutants reduction. The results obtained show major reduction rates in TSS and Turbidity, close to 70\%, and significantly increased the concentration of DO in the water.

On a larger scale, in 2007, the SOSTAQUA research project "Technological Developments towards an urban self-sustaining water cycle" was started, led by AGBAR and with a relevant participation of the University of La Coruña. The project's objective was to ensure self-sustainability of the urban water cycle. This objective would be much more achievable if the requirement of natural resources (water and energy) and the volume of waste generated were lower. The project aims to contribute to this goal by upgrading non-conventional water sources, recovering waste, and minimizing the external energy demand cycle and risky environmental-health-related behavior. There are many publications and conferences from this project, and some studies carried out about the implementation and operation of SUDS are interesting. In 2008, Suárez et al. [65] discussed the applicability of TEDUS in managing urban runoff, highlighting the necessity to incorporate them into master plans that integrate 
the management of water so that they can provide effective control of runoff, both in terms of quality and quantity. Llopart-Mascaró et al. [66] in Novatech 2010 presented the results of a study of outflow water quality from an infiltration trench built in the city of Barcelona, comparing the quality of water entering in it, with the surface runoff. They noted reduction rates of pollution close to $70 \%$ for the set of contaminants studied as could be observed in Figure 13.

Figure 13. Pollutant reduction of filter trench (self-made from results obtained by Llopart-Mascaró et al. [66]).

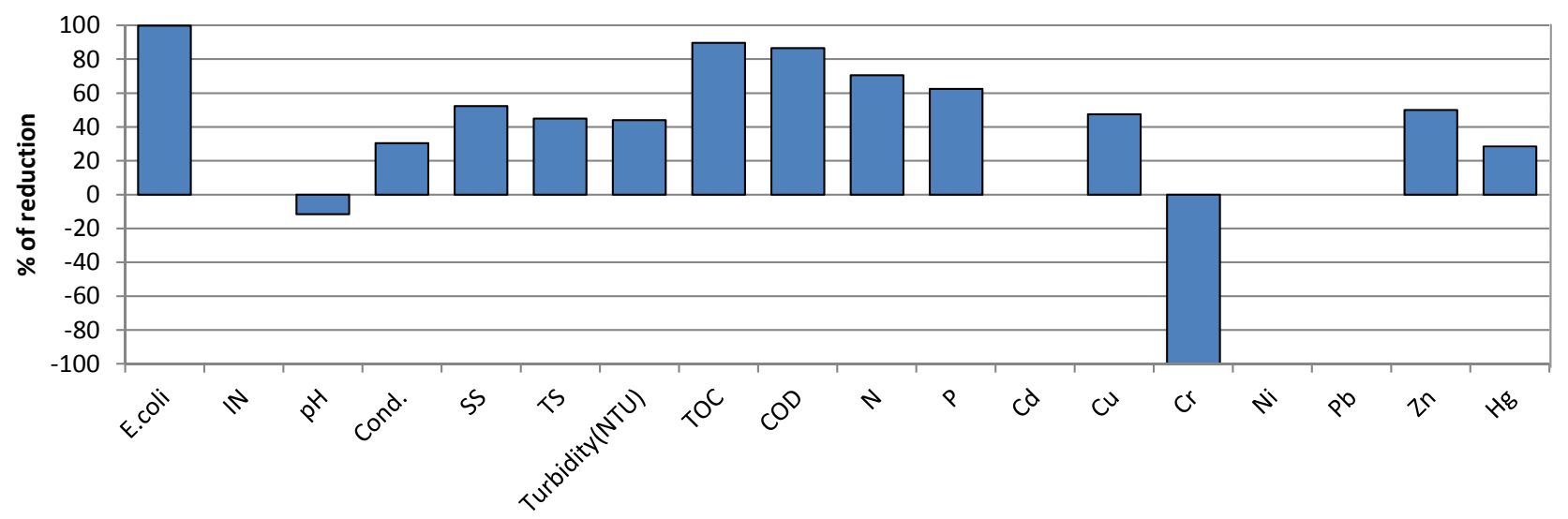

In 2008 and 2009 CEDEX (Centro de Estudios y Experimentación de Obras Públicas) published the two main reference manuals in Spain about SUDS and road stormwater drainage: "Stormwater management: Implications for the design of sanitation and urban drainage" [67] and "Technical Guide for design and management of ponds and other restraints of pollutants on roads" [68].

Also in 2009 the University of Cantabria started another project related to pervious pavements, "Design, control and monitoring of porous pavements built with slag and steel waste" which is currently still in progress. The aim of this project was to evaluate the suitability of using recycled materials in the granular layers of pervious pavements, particularly the performance of BOF-slag in the sub-base layer and its feasibility for implementation in permeable pavements.

Later, in 2010, the project "Development of catchment of stored rainwater systems, using porous pavements in parking lots, for non-potable use with geothermal low-enthalpy energy (VEA)" was started at the University of Cantabria. This project represents a new concept related to sustainable urban construction as it introduces the purpose of storage of rainwater through the use of permeable paving, for reuse in non-potable uses and energy saving. The project raises the possibility of using stored rainwater in two different ways. On the one hand, this water can be used for irrigation of parks and gardens, street cleaning and recreational uses as noted by [62,63]. Furthermore, the stored water provides geothermal use for air conditioning of nearby buildings. To achieve the objective of the VEA project, it developed a system to capture and store water through permeable pavements in car parks with light traffic. At the 12th ICUD, Sañudo-Fontaneda et al [53] reported the project, its objectives and the preliminary results, obtained by laboratory tests, of the effect of clogging on a new type of paving stone (Figure 14). 
Figure 14. (a) Improved Cantabrian Fixed Infiltrometer; (b) Infiltration capacity of ICBP surface for different slopes; (c) Different clogging conditions tested [53]: (1) No clogging, (2) Fully clogged surface and (3) Residual clogging after maintenance.
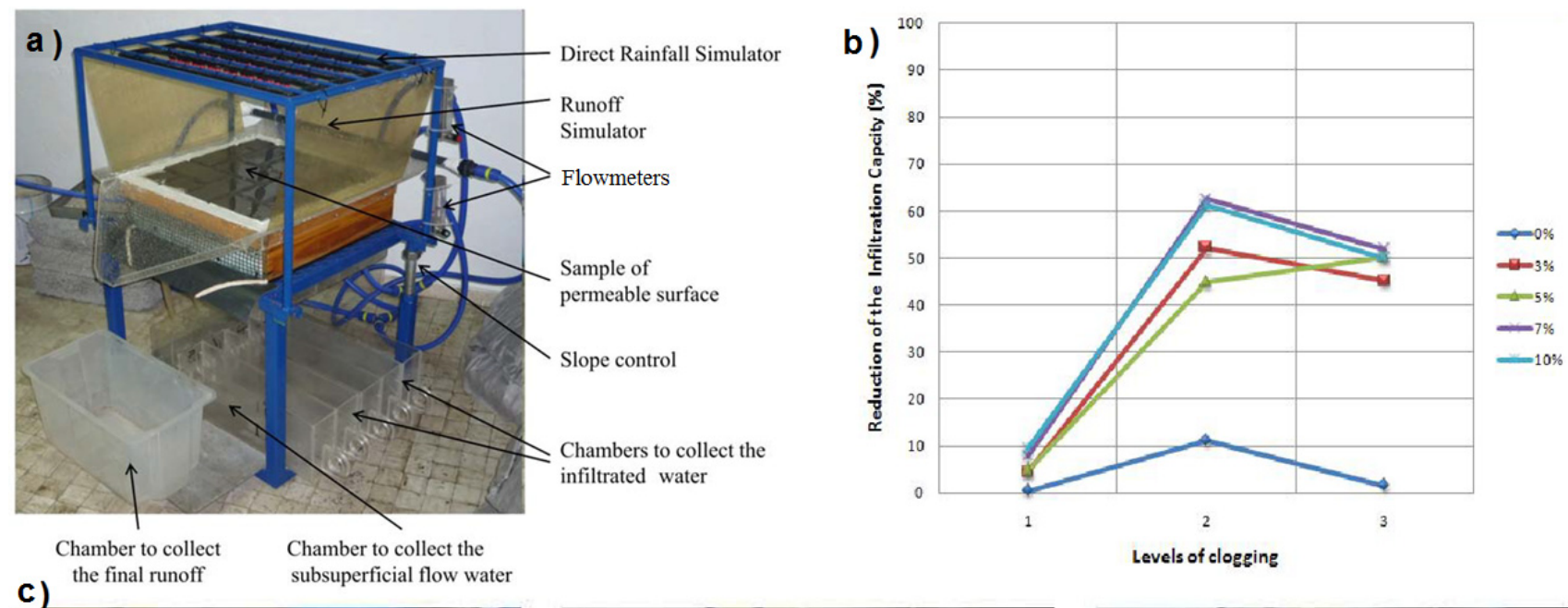

c)
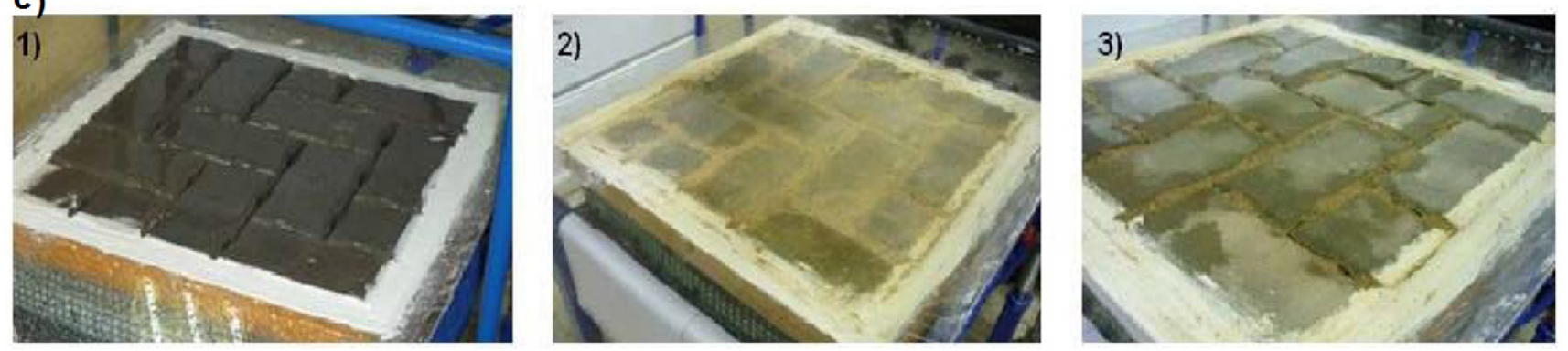

Also in 2010, the Barcelona Sprilur Group published the "Guide for the sustainable development of urban development projects" [69] with considerations relating to SUDS, which is a reference document for architects and developers, mainly in the Basque Country and Catalonia.

In 2010, the EU LIFE project entitled AQUAVAL also began. It followed the indications of the European Project DAYWATER, as a complement to the traditional approach, in order to demonstrate the efficiency of SUDS in southern Europe, through the construction and monitoring of pilot projects in two municipalities of the province of Valencia. Its partners include PMEnginyeria, the University of Abertay Dundee and the municipalities of Xativa and Benaguasil. In 2011 Casal-Campos, Jefferies and Perales-Momparler [70] in the 12th ICUD presented the project and its objectives. The set of actions implemented through the project in the municipalities of Xativa and Benaguasil should be noted. The main objective of these actions, apart from their educational and social awareness function, was to study their ability to mitigate the problems of runoff, especially during periods of "gota fria" (severe weather that brings flooding), and reduce pollution by heavy metals and TSS in southern Europe. The SUDS implemented under the AQUAVAL project were many and varied: pervious pavement filter trenches, dry swales, green roofs, and infiltration basins. In 2011, as part of a post-graduate study in Urban Drainage from AGBAR, an initial inventory of TEDUS in Spain was made. Continuing this line, in 2012, CETAQUA and CLABSA began working in an R and D experience analyzing TEDUS applications in Spain, focusing on the city of Barcelona with three drainage trenches, one infiltration trench, an area of infiltration, and a seepage pit. Due to the nature of the city, the TEDUS applied are of the infiltration type, most of them with peri-urban locations or new construction areas in urban zones. 
With this background, the main challenges for the future are: to prove the positive economic balance of SUDS in Spain, to adapt SUDS to the different climates in Spain, for instance, comparing Atlantic to Mediterranean climate, and carrying out Urban Hydrological Rehabilitation: urban renewal using SUDS, and development of permeable cities.

\section{SUDS Networking in Spain}

The first approach to SUDS networking in Spain occurred in 1999, when ATLANTIS began to be marketed in Spain. With the help of Peter Lasa, publicity was given nationwide to WSUD (Water Sensitive Urban Design) used in Australia. Later, in 2003, SUDSnet, a network group that promotes SUDS technology and its application, was established in the UK with support from an EPSRC (Engineering and Physical Sciences Research Council) network grant. This net was introduced in Spain in 2008 by the University of Cantabria under the name of redSUDS with the same aim, and it is probably the main way for water professionals to exchange ideas and news about SUDS technology.

Another important Spanish networking activity is the SUDS Summer Course organized by the University of Cantabria. The first edition of this course was in 2006 with the relevant participation of Professors Stephen Coupe and Tim Puehmeier of Coventry University, Chris Jefferies of the University of Abertay Dundee and Peter Lasa of Atlantis, among others. The course was attended by Peter Buesa of AMVISA, Roberto Soto of BAGURSA and Sara Perales from PMEnginyeria. The second edition of the course was in 2010, with the important participation of Joaquin Suarez of the University of La Coruña, Roberto Soto from BAGURSA, Joseba Rodriguez from the San Sebastian City Council, Peter Lasa from Atlantis and Sara Perales from PMEnginyeria, among others. The third and fourth SUDS Summer courses were in 2011 and 2012, and managers from Adieco Sustainable BreincoEnviro, Urgarbi, Bagursa, PMEnginyeria and the city of San Sebastian were among the attendants.

The first "Technical Workshop on Sustainable Urban Drainage Systems (SUDS)" was organized in 2007 by the Spanish Civil Engineering Association in Valencia and chaired by Sara Perales from PMEnginyeria with more than 30 attendants. This year the Committee on Urban Drainage AEAS in Murcia discussed the current development of TEDUS in Spain under the name of SUDS and its future potential.

Another noteworthy networking activity, probably the most important in Spain, was the celebration of the International Exposition (EXPO) in the Spanish city of Zaragoza in 2008, with the name of "Water and Sustainable Development," which raised awareness of the scarcity of water, the necessity of water as life support, water landscapes and the use of water for relations among people. In order to fulfill this aim, many water constructions and SUDS applications were built. Among others, the paper on Sustainable Urban Drainage Systems by Sara Perales, entitled "Water and Sustainable Development", was presented in one of the debates of the week, "Water supply and sanitation services".

The development of new materials that could be applied in SUDS construction is very important as is their publicity and application in divulging the concept of sustainable drainage techniques to society at large. The development and commercialization of Ecocreto, which was a special Porous Concrete developed in 1994 and presented in 1996 in Mexico, should be highlighted. It was tested in Mexico, the USA and other countries, and in 2009 EcoCreto-enhanced pervious concrete began to be marketed in Spain with the participation of Adieco Sustainable. 
Later, in 2010, NILSA organized a conference on SUDS with the following lecturers: Chris Jefferies from University of Abertay Dundee, Sara Perales from PMEnginyeria and Jorge Rodriguez from the University of Cantabria.

\section{SUDS Application in Spain}

The application of SUDSs as techniques that help to reduce the runoff problems is quite mature. The first reference found about BMP application was the construction of a detention pond in Monroe (USA) in 1960. Applications in the 1970s include the construction of different swales in different states. Nevertheless, it was not until the 1980s that the first reference about the construction of pervious pavements is found: in 1980, a light traffic car park was built in Dayton (USA) with a grass surface, and, in 1981, another light traffic parking area was built with a porous asphalt surface in Austin (USA) (International BMP Database).

Although SUDS technology has existed since the 1960s, its application in Spain was delayed until after 2000. In this context, there are some cities that made great efforts in order to implement SUDS: notably Madrid, Barcelona, San Sebastian, Oleiros, Gijón, Zaragoza, Santander and, recently, Valencia.

The first SUDs application in Spain was in 2003, when the Madrid City Council applied Atlantis criteria and SUDS technology in the works to remodel the Gomeznarro Park (Figure 15), under the supervision of Javier del Palacio. The work was presented to the UN-Habitat contest on Good Practices and was rated as "Good" in the Best Practices Database. They replaced the conventional roads and impermeable soils with permeable pavements in order to control runoff, and reuse the water for irrigation of adjacent areas. The approval in 2011 by the Madrid City Council of the Madrid Partial Plan APR.08.03 "Castellana Extension" was also significant as it included an attachment on the "Study of Development and Efficient Water Management" by PMEnginyeria for "Chamartín Urban Development, SA". This document includes recommendations to reduce runoff rates through the use of Sustainable Urban Drainage Systems (SUDS). This urban development will probably be the most important in Europe in the coming decades, with the development of about $6 \mathrm{~km}^{2}$ of land along a $3 \mathrm{~km}$ of extension of the Castellana Avenue.

In Barcelona, the first application started two years later than in Madrid. In 2005, Roberto Soto from BAGURSA began to draw up several projects in the city of Barcelona, which contemplated the implementation of SUDS with the collaboration of Atlantis, PMEnginyeria and CLABSA. In 2008, the construction works on projects such as Park of the Torrent of the Nuns and the district of Torre Baro were finished, under the direction of Roberto Soto from BAGURSA. They are relevant for the application of various SUDS for the first time in the city. Later, in 2009, the works on the Area of Knowledge or University Park of Robert Soto from BAGURSA finished, where the application of an infiltration trench in the middle of an avenue is particularly relevant.

San Sebastian carried out some SUDS applications in recent years, starting in 2005 with the work on upgrading the Cristina Enea Park that finished in 2007, becoming the first SUDS application in the city. Later, in 2009, the Ametzagaina Park and Philip IV Sports Arena works ended, with several outstanding features related to sustainable drainage, and in 2010, the Mount Ulia works were completed, including several SUDS in the city. 
Figure 15. Gomeznarro Park [71]. (a) General view; (b) Finished pervious pavement; (c) Construction of pervious pavement.

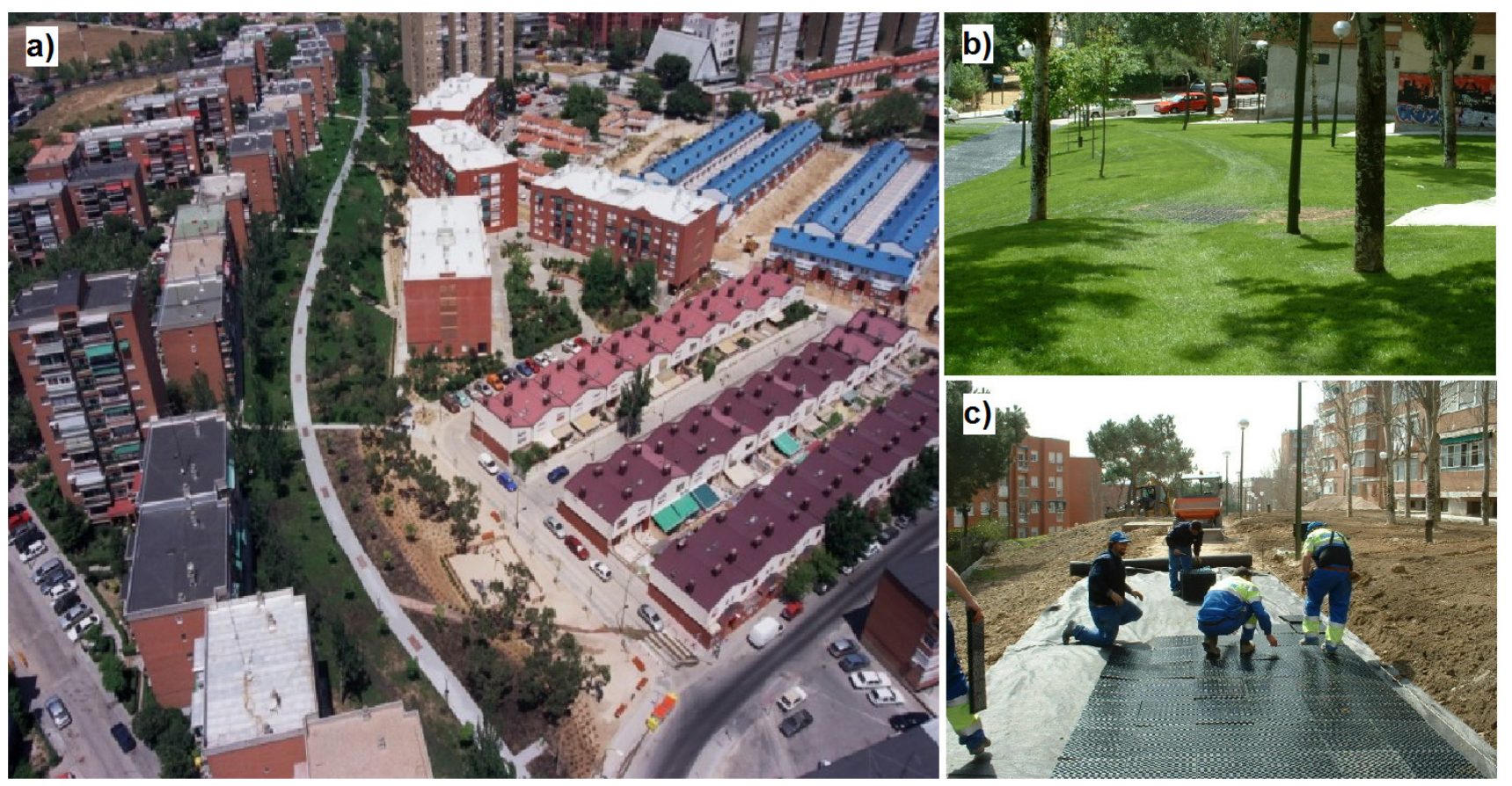

Oleiros, a little residential town in the north of Spain, is also significant as in 2005, it became a pioneer in implementing SUDS at the local level, where various Atlantis products were applied.

The first pervious pavement application in Spain was in 2005, when Gijón City Council built "La Guia" open air car park (Figure 16), with 700 Atlantis plastic-cell-reinforced grass parking lots. The first 15 lots were used to test different pervious pavements as a part of the FIDICA project carried out by the University of Cantabria with the collaboration of Coventry University and the University of Oviedo.

Figure 16. La Guia car park [71]. (a) Construction Phase; (b) Final Result.
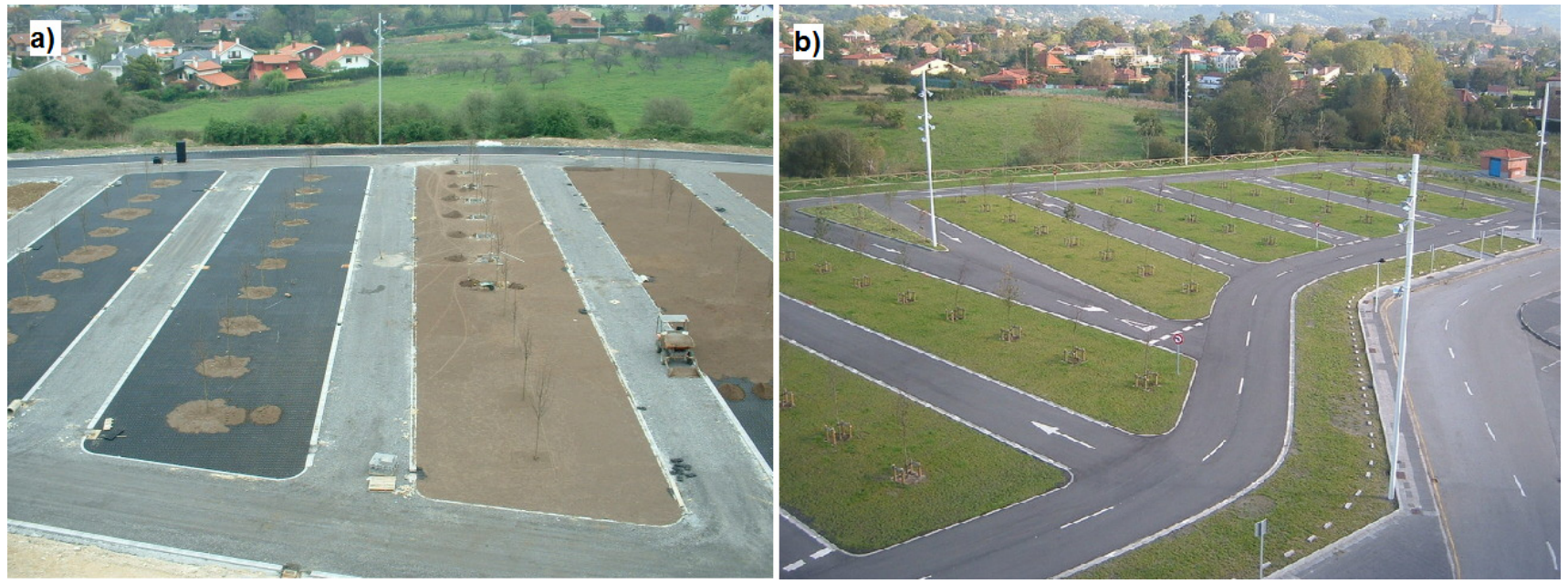
In the International Exposition of 2008 (EXPOZARAGOZA), with the slogan "Water and urban development," Zaragoza made great efforts to execute various SUDS applications in the area of the Exposition. These works include numerous applications of SUDS criteria, ecological roofs, pervious pavement, vegetation in walls, and deposits for infiltration of rainwater.

In 2008, the city of Santander completed the construction of the first phase of "Las Llamas" Park, (Figure 17), which has an artificial wetland and 45 experimental parking lots with different surfaces: paved, porous asphalt, porous concrete, grass reinforced with concrete and plastic cells, as part of another research project carried out by the University of Cantabria.

With the start of the AQUAVAL project, some SUDS applications began to be developed in Valencia. In 2011, the first open air porous concrete car park was inaugurated in Benaguasil; apart from this, there are more SUDS under construction in Benaguasil and Xativa, which will be finished in 2012 and 2013.

Figure 17. (a) La Vaguada de las llamas park; (b) Pervious Pavement experimental car park; (c) Artificial Wetland.

a)
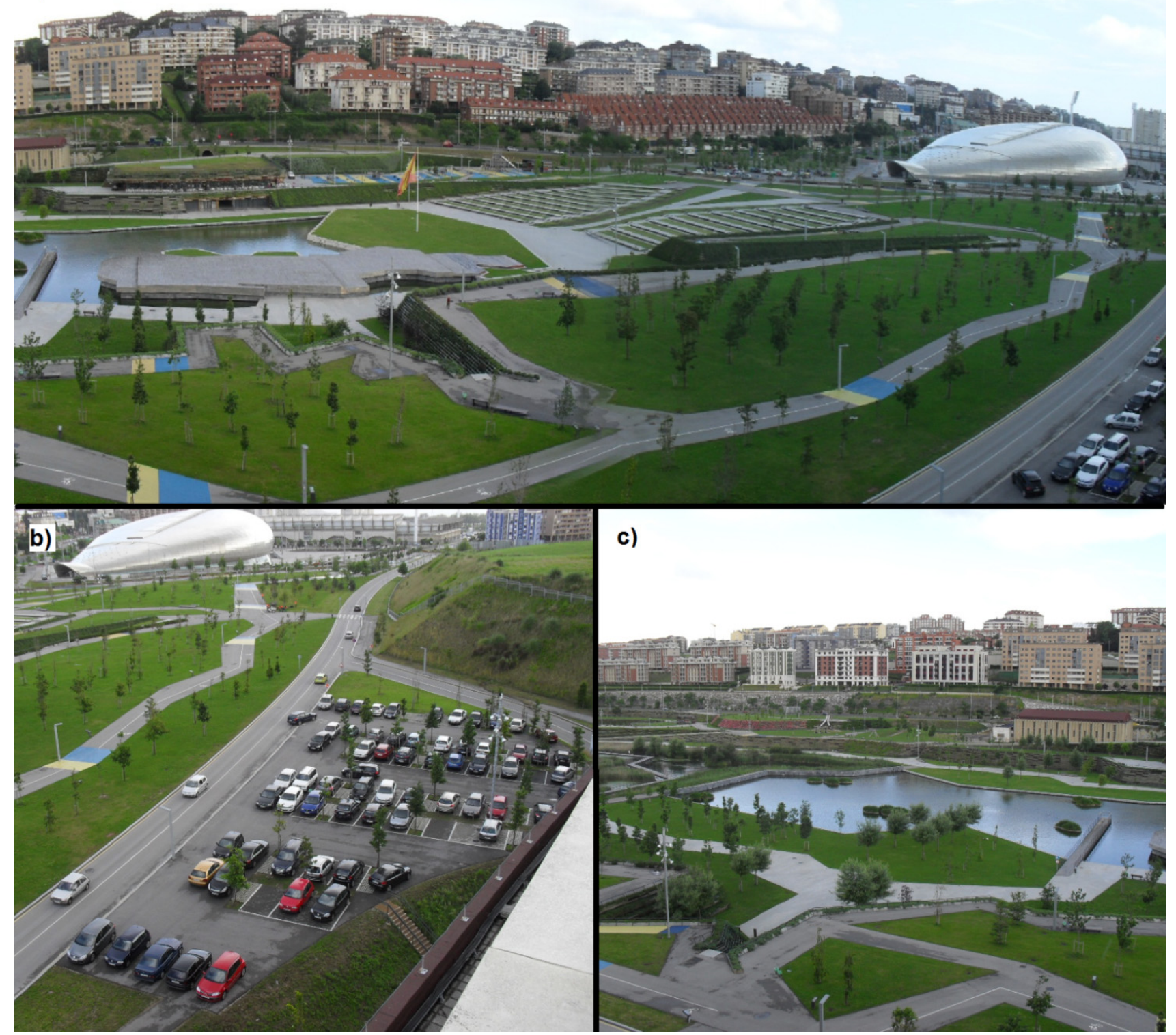

c)

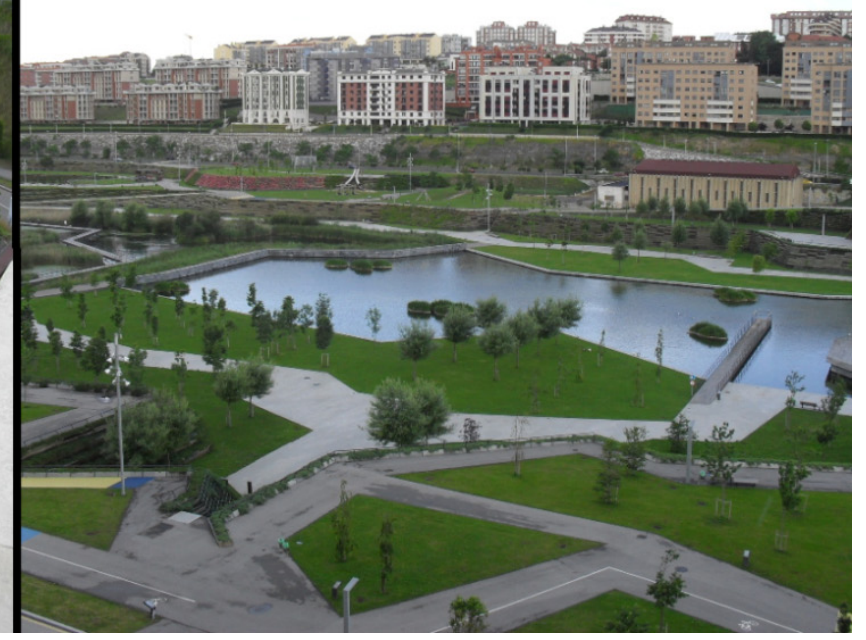




\section{Conclusions}

Water legislation in Spain has suffered long delays compared to other more developed countries. Thus, while the UK was controlling wastewater quality and, in the USA, they had already discovered diffuse pollution and were beginning to implement BMPs, Spain had not yet grasped the concept of water quality. However, the entry into the EU marked a turning point in this situation, provoking a considerable effort over the last twenty years to accommodate European regulatory directives, in particular the Water Framework Directive. The most recent Spanish legislation, which contemplates and regulates water regeneration concepts, flood control, and stormwater management through the application of innovative systems that increase infiltration is noteworthy in this regard.

The importance of the University of Cantabria in carrying out the first Spanish studies related to diffuse pollution and in starting, with the collaboration of the University of Coventry, the first research line about SUDS in Spain in 2003 should be noted. This research line has been very productive scientifically, with a total of 13 projects developed regarding SUDS technologies and pervious pavements, 12 scientific papers in JCR indexed journals, 20 participations in national and international conferences and 2 exploitation patents. Moreover, the implementation of the European-funded AQUAVAL Project in the Valencia region provides a complement to the DAYWATER Project.

The networking effort made by the different entities involved in research, development, construction and marketing of SUDS mainly focuses on creating redSUDS and organizing summer courses at the University of Cantabria.

The actual implementation of SUDS in Spain is still in its early stages, but the actions carried out in the cities of Madrid, Barcelona, San Sebastian, Santander, Gijón, Oleiros, Xativa and Benaguasil should be highlighted.

The main challenges for the future are: to prove the positive economic balance of SUDS in Spain, to adapt SUDS to the different climates in Spain, for instance, comparing Atlantic to Mediterranean climate, and to carry out Urban Hydrological Rehabilitation, that is, urban renewal using SUDS and development of permeable cities.

\section{Acknowledgments}

This paper was possible thanks to the collaboration of Pere Malgrat, Javier Temprano, Pedro Lasa, Sara Perales, Roberto Soto, Joaquín Suarez, Francisco Ballester, Angel Vega, Juan Carlos Canteras, Nelson González, Stephen Coupe, Sue Charlesworth, Xavier Moreno-Ventas, John Davies and Alan Newman. The main core of this research line of the Construction Technology Research Group (GITECO), with the support of the Roads Research Group and the Ecology Research Group of the University of Cantabria, are the following projects financed by the Spanish Government: REN2003-05278/TECNO; CTM2006-00310/TECNO, BIA2009-08272 and BIA2012-32463.

\section{References}

1. Segura Graiño, R. The water in Spain: Problems and solutions [in Spanish]. Bol. Asoc. Geogr. Esp. 1994, 18, 29-38. 
2. Domínguez Bascón, P. Specification of environmental problems of the city in urban Spanish planning legislation in the nineteenth century [in Spanish]. Ería 2002, 57, 49-56.

3. Molinos-Senante, M.; Hernandez-Sancho, F.; Sala-Garrido, R. Current status and evolution of sanitation and wastewater treatment in the national and international context [in Spanish]. An. Geogr. 2012, 32, 68-89.

4. Gutierrez Ayuso, A. Contribution to the knowledge of the Spanish-Muslim cisterns of Extremadura: Typology of an example of water architecture [in Spanish]. NORBA-ARTE 2001, 20-21, 7-27.

5. Galiana, M.E.; Bernabeu-Mestre, J. The health problem in Spain: Sanitation and rural zones in the first decades of the twentieth century [in Spanish]. Asclepio Rev. Hist. Med. Cienc. 2006, 58, $139-164$.

6. Dolz, J.; Gómez, M. Problems of stormwater drainage in urban areas and about the hydraulic study of collector networks [in Spanish]. Dren. Urbano 1994, 1, 55-66.

7. Dauphiné, A. Risques et Catastrophes: Observer, Spatialiser, Comprendre, Gérer [in French]; Armand Colin: Paris, France, 2001.

8. Campbell, N.A.; D’Arcy, B.; Frost, A.; Novotny, V.; Sansom, A. Diffuse Pollution: An Introduction to the Problems and Solutions; IWA Publishing: London, UK, 2004.

9. Novotny, V. Water Quality: Diffuse Pollution and Watershed Management, 2nd ed.; Wiley: New York, NY, USA, 2003.

10. Water Act of 3 August 1866 [in Spanish]; Spanish Government: Madrid, Spain, 1866.

11. Water Act of 13 June 1879 [in Spanish]; Spanish Government: Madrid, Spain, 1879.

12. Regulation of Works, Services and Municipal Assets of 14 July 1924 [in Spanish]; Spanish Government: Madrid, Spain, 1924.

13. Federal Water Pollution Control Act. U.S. Code, Section 1251-1376, Title 33, Public Law 80-845, 62 Stat. 1155, 1948; 2000.

14. Clean Water Act. U.S. Code, Section 1251-1376, Title 33, Public Law 92-500, 86 Stat. 816, 1977; 2000.

15. Water Quality Act. Public Law. U.S. Code, Public Law 100-4, 1987.

16. Act 29/1985 of 2 August: Water Act [in Spanish]. Boletin Oficial del Estado 1985, 189, 25123-25135.

17. Directive 75/440/EEC of 16 June 1975 Concerning the Quality Required of Surface Water Intended for the Abstraction of Drinking Water in the Member States; Official Journal Journal of the European Communities: Brussel, Belgium, 1975.

18. Directive 91/271/EEC 21 May 1991 Concerning Urban Waste-Water Treatment; Official Journal No. 135, Brussel, Belgium, 1991.

19. Directive 2000/60/EC of the European Parliament and the Council of 23 October 2000 Establishing a Framework for Community Action in the Field of Water Policy; Official Journal of the European Communities: Brussel, Belgium, 2000.

20. Directive 2007/60/EC of the European Parliament and of the Council of 23 October 2007 on the Assessment and Management of Flood Risks Text with EEA Relevance; Official Journal of the European Communities: Brussel, Belgium, 2007.

21. Legislative Royal Decree 1/2001 of 20 July by Approving the Revised Text of Water Act [in Spanish]. Boletín Oficial del Estado 2001, 176, 26791-26817. 
22. Royal Decree 606/2003, of 23 May, that Modificate the Royal Decree 849/1986, of 11 April, which Approved the Regulations of Hidraulic Public Domain [in Spanish]. Boletín Oficial del Estado 2003, 134, 22071-22096.

23. Act 10/2001 of 5 July, of the National Hydrologic Plan [in Spanish]. Boletín Oficial del Estado 2001, 161, 24228-24250.

24. Royal Decree 1620/2007 of 7 December, that Establish the Legal Status of the Reutilization of Depurated Water [in Spanish]. Boletin Oficial del Estado 2007, 294, 50639-50661.

25. Royal Decree 1290/2012 of 7 September Amending both the Royal Decree both 849/1986 of 11 April, Approving the Regulation of Public Water, and Royal Decree 509/1996 of 15 March, to Royal Decree Law 11/1995 of December 28, Laying Down Rules for the Treatment of Urban Waste Water [in Spanish]. Boletín Oficial del Estado 2012, 227, 66167-66194.

26. CLABSA and Barcelona City Council. The Special Sewage System Plan of Barcelona [in Spanish]; Barcelona City Council: Barcelona, Spain, 1997.

27. Madrid City Council. Ordinances for the Efficient Use of Water in the Madrid City [in Spanish]; Madrid City Council: Madrid, Spain, 22 June 2006; pp. 2410-2443.

28. Madrid City Council. Best Practices in Architecture and Urbanism [in Spanish]; Government and Urbanism Area: Madrid, Spain, 2009.

29. Xunta de Galicia; Aguas de Galicia; EPOSH. Technical Instructions for Waterworks in Galicia [in Spanish]; Xunta de Galicia: Galicia, Spain, 2009.

30. EPA 430/9-73-014: Methods for Identifying and Evaluating the Nature and Extent of Nonpoint Source of Pollutants; U.S Environment Protection Agency: Washington, DC, USA, 1973.

31. Thelen, E.; Grover, W.C.; Hoiberg, A.J.; Haigh, T.I. Investigation of Porous Pavements for Urban Runoff Control; 11034 DUY 03/72; U.S. Environmental Protection Agency: Washington, DC, USA, 1972.

32. Pratt, C.J. Storm water infiltration techniques as an aid to flow reduction in urban watercourses and sewer systems. Hydraul. Floods Flood Control 1985, 1, 265-276.

33. Pratt, C.J.; Mantle, J.D.G.; Schofield, P.A. Urban stormwater reduction and quality improvement through the use of permeable pavements. Water Sci. Technol. 1989, 21, 769-778.

34. D'Arcy, B.; Frost, A. The role of best management practices in alleviating water quality problems associated with diffuse pollution. Sci. Total Environ. 2001, 265, 359-367.

35. Cervigni, M.G. Systems to Control and Treat the CSOs. Optimization of the binomial Tank-Decanter [in Spanish]. Master's Thesis, University of Cantabria, Cantabria, Spain, 1 January 1993.

36. Temprano González, J. Dimensioning Criteria for Storm Tanks in Santander [in Spanish]. Ph.D. Thesis, University of Cantabria, Cantabria, Spain, 1 January 1997.

37. Cano, A. Characterization of Urban Contamination in Rainy weather [in Spanish]. Master's Thesis, University of Cantabria, Cantabria, Spain, 1 January 1996.

38. Malgrat, P. Overview of the Stormwater Runoff as a Source of Contamination: Possible Actions [in Spanish]. In Proceedings of Workshop Benicassim, Benicassim, Spain, 28 November-1 December 1995.

39. Temprano González, J.; Gabriel Cervigni, M.; Suárez López, J.; Tejero Monzón, J.I. Contamination in sewer systems with rainy weather: Source Control [in Spanish]. Revista Obras Publicas 1996, 3352, 45-57. 
40. González del Tánago, M. Impact of agriculture on river systems: Restoration techniques for soil and water conservation [in Spanish]. Agric. Soc. 1996, 78, 211-236.

41. Jimenez Gallardo, B.R. Pollution from Urban Runoff; SEINOR Collection No. 22; Spanish Civil Engineering Association: Madrid, Spain, 1999.

42. Scholes, L.N.L.; Revitt, D.M.; Ellis, J.B. A European project (DayWater) investigating the integration of stormwater source control into sustainable urban water management strategies. J. Health Soc. Environ. Issues 2003, 4, 37-40.

43. Rodriguez, J.; Castro, D.; Calzada, M.A.; Davies, V. Pervious Pavement Research in Spain: Structural and Hydraulic Issues. In Proceedings of the 10th International Conference on Urban Drainage (ICUD), Copenhagen, Denmark, 21-26 August 2005.

44. Bayon, J.R.; Castro, D.; Moreno-Ventas, X.; Coupe, S.J.; Newman, A.P. Pervious Pavement Research in Spain: Hydrocarbon Degrading Microorganisms. In Proceedings of the 10th International Conference on Urban Drainage (ICUD), Copenhagen, Denmark, 21-26 August 2005.

45. Fresno, D.C.; Bayón, J.R.; Hernández, J.R.; Muñoz, F.B. Sustainable urban drainage systems (SUDS). Interciencia 2005, 30, 255-260,306-308.

46. Fernández-Barrera, A.H.; Castro-Fresno, D.; Rodríguez-Hernández, J.; Calzada-Pérez, M.A. Infiltration capacity assessment of urban pavements using the LCS permeameter and the CP infiltrometer. J. Irrig. Drain. Eng. 2008, 134, 659-665.

47. Davies, J.W.; Pratt, C.J.; Scott, M.A. Laboratory Study of Permeable Pavement Systems to Support Hydraulic Modeling. In Proceedings of the 9th International Conference on Urban Drainage (ICUD), Portland, OR, USA, 8-13 September 2002.

48. Castro, D.; González-Angullo, N.; Rodríguez, J.; Calzada, M.A. The influence of paving-block shape on the infiltration capacity of permeable paving. Land Contam. Reclam. 2007, 15, 335-344.

49. Castro Fresno, D.; Rodríguez Hernández, J.; Rodríguez Bayón, J.; Ballester Muñoz, F.; González Angulló, N. Interlocking Concrete Block [in Spanish]. Spanish Patent: Industrial Design D0502335 1-4, 11 November 2005.

50. Rodriguez-Hernandez, J. Study, Analysis and Design of Permeable Sections of Pavements for Urban Roads with an Appropriate Behaviour Facing Blockage and the Needed Bearing Capacity to Support Light Traffic [in Spanish]. Ph.D. Thesis, University of Cantabria, Cantabria, Spain, 11 July 2008.

51. González-Angullo, N.; Castro, D.; Rodríguez-Hernández, J.; Davies, J.W. Runoff infiltration to permeable paving in clogged conditions. Urban Water J. 2008, 5, 117-124.

52. Rodriguez-Hernandez, J.; Castro-Fresno, D.; Fernández-Barrera, A.H.; Vega-Zamanillo, Á. Characterization of infiltration capacity of permeable pavements with porous asphalt surface using cantabrian fixed infiltrometer. J. Hydrol. Eng. 2012, 17, 597-603.

53. Sañudo-Fontaneda, L.A.; Castro-Fresno, D.; Rodriguez-Hernandez, J.; Borinaga-Treviño, R. Comparison of the Infiltration Capacity of Permeable Surfaces for Rainwater Energy Valorization. In Proceedings of the 12th International Conference on Urban Drainage (ICUD), Porto Alegre, Brazil, 11-16 September 2011.

54. Sañudo-Fontaneda, L.A.; Rodriguez-Hernandez, J.; Vega-Zamanillo, A.; Castro-Fresno, D. Laboratory analysis of the infiltration capacity of interlocking concrete block pavements in car parks. Water Sci. Technol. 2012, 67, 675-681. 
55. CEDEX. Permeabilidad in situ de Pavimentos Drenantes con el Permeámetro LCS; NLT-327/00; Dirección General de Carreteras: Madrid, Spain, 2000.

56. Rodriguez-Hernandez, J.; Fernández-Barrera, A.H.; Andrés-Valeri, V.C.A.; Vega-Zamanillo, A.; Castro-Fresno, D. Review of the relation between runoff pollutant and catchment characteristics. J. Irrig. Drain. Engin. 2013, Submitted.

57. Rodriguez-Hernandez, J.; Fernández-Barrera, A.H.; Castro-Fresno, D.; Vega-Zamanillo, A. Long-term simulation of a system for catchment, pretreatment, and treatment of polluted runoff water. J. Environ. Eng. 2010, 136, 1442-1446.

58. Fernández-Barrera, A.H.; Rodriguez-Hernandez, J.; Castro-Fresno, D.; Vega-Zamanillo, A. Laboratory analysis of a system for catchment, pre-treatment and treatment (SCPT) of runoff from impervious pavements. Water Sci. Technol. 2010, 61, 1845-1852.

59. Fernández-Barrera, A.H.; Castro-Fresno, D.; Rodriguez-Hernandez, J.; Vega-Zamanillo, Á. Long-term analysis of clogging and oil bio-degradation in a system of catchment, pre-treatment and treatment (SCPT). J. Hazard. Mater. 2011, 185, 1221-1227.

60. Gomez-Ullate, E.; Novo, A.V.; Bayón, J.R.; Rodriguez-Hernandez, J.; Castro-Fresno, D. Design and Construction of an Experimental Pervious Paved Parking Area to Harvest Reusable Rainwater. In Proceedings of the 7th International Conference on Sustainable Techniques and Strategies in Urban Water Management (NOVATECH 2010), Lyon, France, 27 June-1 July 2010.

61. Gomez-Ullate, E. Analysis of Pervious Pavement Car Park for the increase of Sustainable Management of Urban Water through the storage and valorisation of Stormwater [in Spanish]. Ph.D. Thesis, University of Cantabria, Cantabria, Spain, 7 February 2011.

62. Gomez-Ullate, E.; Castillo-Lopez, E.; Castro-Fresno, D.; Bayon, J.R. Analysis and contrast of different pervious pavements for management of storm-water in a parking area in Northern Spain. Water Resour. Manag. 2011, 25, 1525-1535.

63. Gomez-Ullate, E.; Novo, A.V.; Bayon, J.R.; Hernandez, J.R.; Castro-Fresno, D. Design and construction of an experimental pervious paved parking area to harvest reusable rainwater. Water Sci. Technol. 2011, 64, 1942-1950.

64. Andrés-Valeri, V.C.A.; Castro-Fresno, D.; Sañudo-Fontaneda, L.A.; Rodriguez-Hernandez, J. Comparative analysis of the outflow water quality of three linear drainage systems in a roadside car park in Spain. J. Environ. Eng. 2013, Submitted.

65. Suárez, J.; Jácome, A.; Puertas, J.; Del Río, H. Management Problems of Pollution Associated with Stormwater [in Spanish]. In Proceedings of the 8th Spanish National Committee of Water Treatment [Mesa Española de Tratamiento de Aguas (META)], Tenerife, Spain, 4-6 December 2008.

66. Llopart-Mascaró, A.; Ruiz, R.; Martínez, M.; Malgrat, P.; Rusiñol, M.; Gil, A.; Suárez, J.; Puertas, J.; Rio, H.; Paraira, M.; Rubio, P. Analysis of Rainwater Quality: Towards Sustainable Rainwater Management in Urban Environments-Sostaqua Project. In Proceedings of the 7th International Conference on Sustainable Techniques and Strategies in Urban Water Management (NOVATECH 2010), Lyon, France, 27 June-1 July 2010.

67. Puertas Agudo, J.; Suárez López, J.; Alvarez Anta, J. Stormwater Management: Implications for the Design of Sanitation Systems and Urban Drainage; Monographs M-98; CEDEX-Centre for Hydrographic Studies, Spanish Ministry of Public Words: Madrid, Spain, 2008. 
68. Rodríguez Sánchez, J.J.; Diaz Martínez, A. Technical Guide to Design and Manage Ponds and Other Restraints of Pollutants on Roads; Manuals and Recommendations R-18; CEDEX-Centre for Applied Techniques Studies, Ministry of Public Works: Madrid, Spain, 2009.

69. Guide for the Sustainable Development of Urban Development Projects; Sprilur: Barcelona, Spain, 2010.

70. Casal-Campos, A.; Jefferies, C.; Perales-Momparler, S. Selecting SUDS in the Valencia Region of Spain. In Proceedings of the 12th International Conference on Urban Drainage (ICUD), Porto Alegre, Brazil, 11-16 September 2011.

71. Sistemas Urbanos de Drenaje Sostenible Web Page. Nuestras Referencias. Available online: http://www.drenajesostenible.com/referencias/\# (accessed on 25 September 2012).

(C) 2013 by the authors; licensee MDPI, Basel, Switzerland. This article is an open access article distributed under the terms and conditions of the Creative Commons Attribution license (http://creativecommons.org/licenses/by/3.0/). 